Portland State University

PDXScholar

Center for Lakes and Reservoirs Publications

and Presentations

$12-2007$

\title{
Report on Nutria Management and Research in the Pacific Northwest
}

Trevor Sheffels

Portland State University

Mark Sytsma

Portland State University

Follow this and additional works at: https://pdxscholar.library.pdx.edu/centerforlakes_pub

Part of the Fresh Water Studies Commons

Let us know how access to this document benefits you.

\section{Citation Details}

Sheffels, Trevor and Sytsma, Mark, "Report on Nutria Management and Research in the Pacific Northwest" (2007). Center for Lakes and Reservoirs Publications and Presentations. 24.

https://pdxscholar.library.pdx.edu/centerforlakes_pub/24

This Technical Report is brought to you for free and open access. It has been accepted for inclusion in Center for Lakes and Reservoirs Publications and Presentations by an authorized administrator of PDXScholar. Please contact us if we can make this document more accessible: pdxscholar@pdx.edu. 


\section{Report on Nutria Management and Research in the Pacific Northwest}

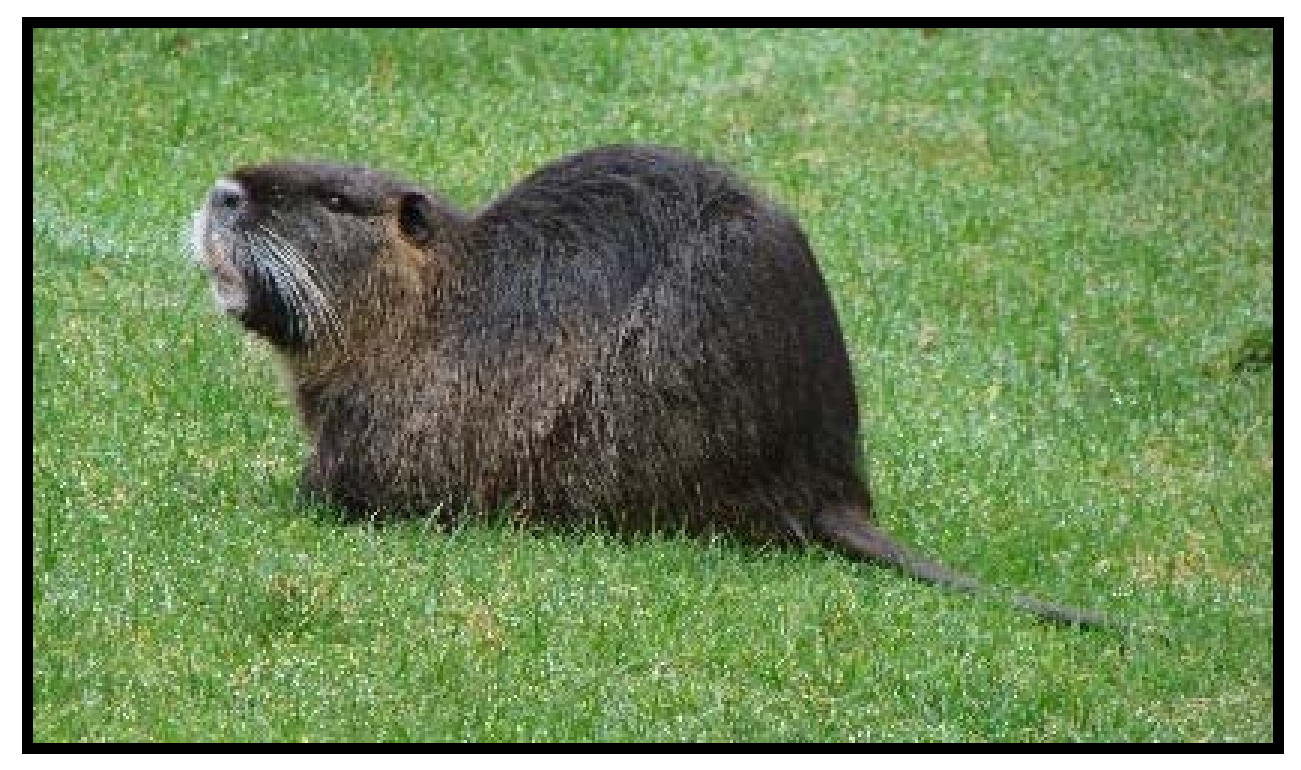

\section{(f) Portland State}

Center for Lakes and Reservoirs

Environmental Sciences \& Resources 


\section{Report on Nutria Management and Research in the Pacific Northwest}

Prepared for the

United States Geological Survey, National Wetlands Research Center

United States Fish and Wildlife Service, Pacific Region

Environmental Protection Agency, Region 10

Oregon Department of Fish and Wildlife, Invasive Species and Wildlife Integrity Program

Washington Department of Fish and Wildlife, Aquatic Nuisance Species Program

Clean Water Services, Water Resources Program

Written by:

Trevor Sheffels and Mark Sytsma

Center for Lakes and Reservoirs

Environmental Sciences \& Resources

\section{\& Portland $\mathbb{S}_{\text {NIVERSITY }}^{\text {State }}$}

December 2007 


\section{Acknowledgements}

We would like to thank everyone who participated in the production of this report. Jacoby Carter of the United States Geological Survey and Paul Heimowitz of the United States Fish and Wildlife Service assisted in organizing the regional nutria workshop and provided suggestions and guidance. Jim Gores of the Oregon Department of Fish and Wildlife and Pamala Meacham of the Washington Department of Fish and Wildlife assisted in the creation of the regional nutria distribution map. Brian Vaughn of Clean Water Services provided the sites and resources to conduct research on nutria impacts on habitat restoration projects. Stacey VonDerahe and Ashley Seim of Clean Water Services provided assistance for plant species identification and GIS application respectively. The Cascade Education Crew assisted in the construction of exclosures for field research. Gary Witmer provided night vision binoculars for determining relative nutria population densities at the study sites. The Vancouver Water Resources Education Center and the United States Geological Survey Cascades Volcano Observatory donated the use of their facilities for the regional nutria workshop. Robyn Draheim of the Center for Lakes and Reservoirs provided guidance, advice, and suggestions throughout the project. Finally, thank you to Joe Maser, Jim Gores, Paul Heimowitz, Jacoby Carter, Sergio Merino, and Tom Kellie for reviewing this report.

The United States Geological Survey National Wetlands Research Center and the United States Fish and Wildlife Service Pacific Region provided funding support for the workshop, research project, and graduate student stipend. The Environmental Protection Agency Region 10 also provided funding for the workshop. The Washington Department of Fish and Wildlife Aquatic Nuisance Species Program contributed funds and resources for the workshop and distribution/density map respectively. The Oregon Department of Fish and Wildlife Invasive Species and Wildlife Integrity Program also provided resources for the distribution/density map. The Clean Water Services Water Resources Program contributed funding for the workshop, research materials, and questionnaire. 


\section{Executive Summary}

The nutria (Myocastor coypus) is a large semi-aquatic mammal native to South America that has been introduced to numerous countries around the world, primarily for fur farming. Nutria were introduced in Oregon and Washington in the 1930s, and feral populations were documented in 1943. Populations are known to be expanding in both Oregon and Washington, and regional nutria damage and nuisance complaints have increased in recent years. Most of the extensive damage caused by nutria is a direct result of feeding and burrowing, but nutria are also capable of transporting parasites and pathogens transmittable to humans, livestock, and pets.

Although several past regional and local nutria research and management projects have been identified, there is a shortage of nutria information from the Pacific Northwest considering that the species has been present in the region for approximately seventy years. The Center for Lakes and Reservoirs (CLR) at Portland State University (PSU), in partnership with several local, state, and federal agencies, has taken the lead in addressing the regional nutria problem. Activities completed to date include a regional nutria management workshop, the ongoing development of a regional nutria distribution/density map, and a research project to analyze the impact of nutria herbivory on regional riparian wetland habitat restoration projects. In addition, the CLR at PSU is participating in the development of the national Aquatic Nuisance Species Task Force nutria management plan.

This initial assessment of the current nutria situation in the Pacific Northwest conducted by the CLR at PSU has revealed that regional nutria problems are more extensive than previously realized. Nutria sightings have now been confirmed from the Canadian border to near the southern border of Oregon, confirming a larger range than was previously known. It was also found that the main nutria issues in the Pacific Northwest differ from the main nutria issues in Louisiana and Maryland. For example, the most significant category of regional nutria damage appears to be the destruction of water control structures and associated erosion caused by nutria burrowing, as opposed to nutria herbivory damage in Louisiana and Maryland. Another unique situation in the Pacific Northwest is the high density of nutria populations in urban areas, increasing the potential for conflicts between nutria and humans. Nutria attacks have been reported in isolated cases, and nutria are rodents that carry a variety of transmittable parasites and pathogens. It has also been confirmed that significant regional nutria herbivory damage does occur at some locations. 
Fortunately, it has become evident through the course of this assessment that a strong regional interest to address the nutria problem exists. A wide variety of agencies and organizations across the region are being negatively impacted by nutria, and these entities are ready to move forward to develop a feasible solution. To date, small-scale nutria management and eradication efforts have been somewhat effective temporarily, but a more permanent solution requires that the situation be addressed on a much larger scale. Due to the long period of time since the initial nutria introduction, the extent of current regional nutria populations, and the changing climate patterns, a long-term effort will likely be required to effectively address the regional nutria issue.

The most immediate management need is to develop an official regional nutria management plan with the focus of greatly reducing the amount of damage being caused by this invasive rodent and preventing further population growth and expansion. The effectiveness of initial management efforts will shed light on how to adapt management strategies in the future and whether or not regional eradication is a feasible option. Continued nutria research and the development of coordinated management efforts at the regional scale are vital in order to bring the current regional nutria problem under control.

The CLR at PSU has developed initial recommendations to help guide the process of determining how to most effectively manage nutria in the Pacific Northwest. First and foremost, funding sources for continued work on the regional nutria problem must be found. Once funding is secured, the development of an official nutria regional management plan is crucial. Priorities connected with the management plan would include creating an early detection rapid response plan, identifying best management practices, initiating a pilot eradication program, and identifying priority research needs. Potential research studies include a long-term pilot eradication project at the watershed level, relationships between climate change and regional nutria dispersal, and the dynamics of nutria-muskrat interactions. It is also evident that further coordination between local, state, and federal agencies is necessary to delegate responsibilities and keep all parties updated. The creation of a central regional database and appropriate agency protocols could be used to collect information about nutria damage and associated economic impacts. Current laws and regulations pertaining to nutria should be enforced and possibly updated so that Oregon and Washington laws are uniform. Finally, it is important to inform the public about current nutria issues and utilize resources the general public can potentially provide. 


\section{Table of Contents}

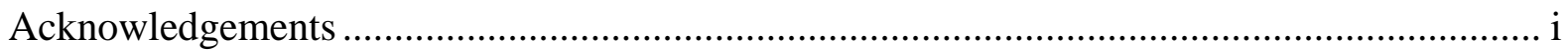

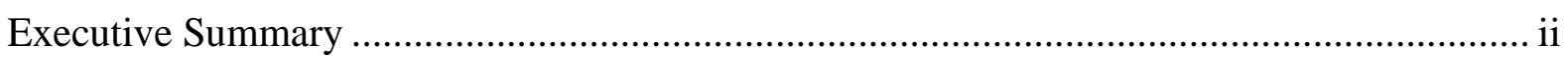

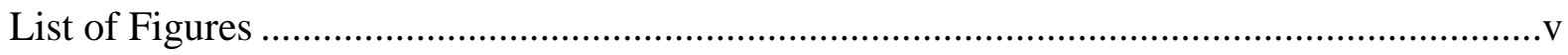

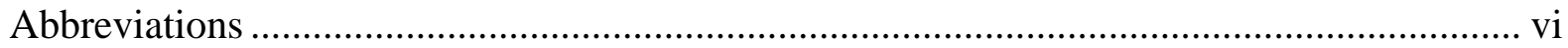

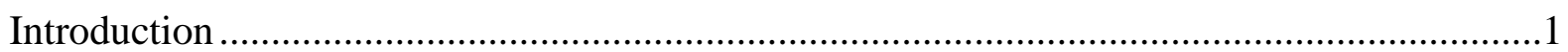

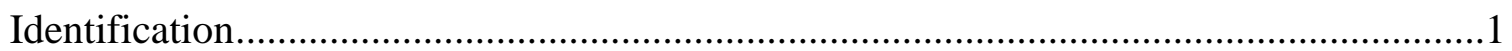

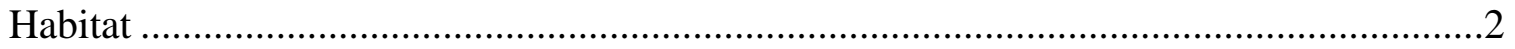

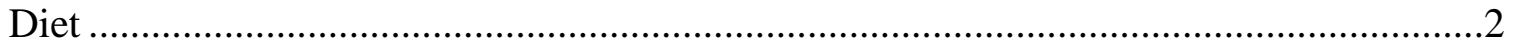

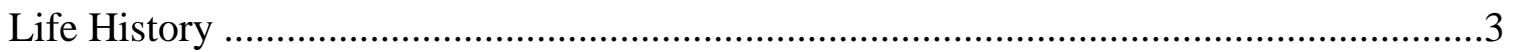

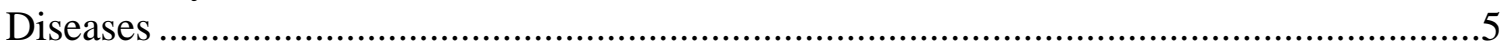

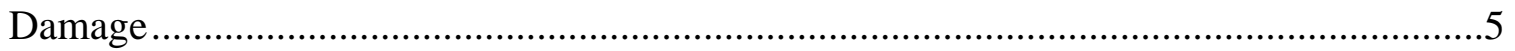

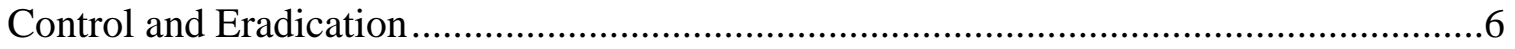

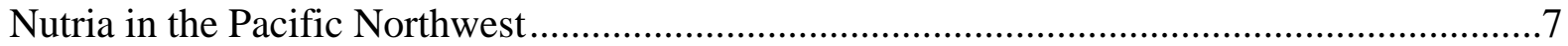

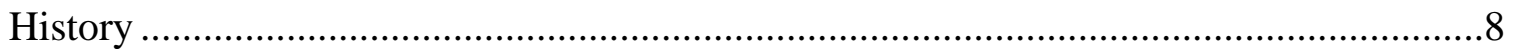

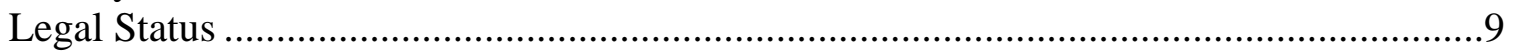

Past Regional Research and Management Efforts.....................................................

Center for Lakes and Reservoirs at Portland State University Nutria Project ........................10

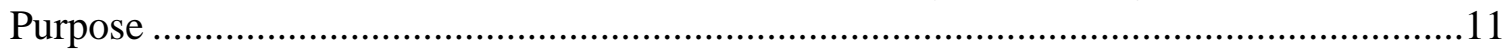

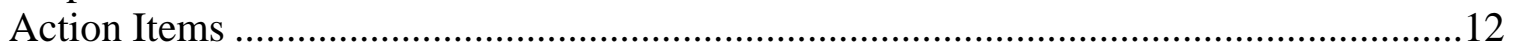

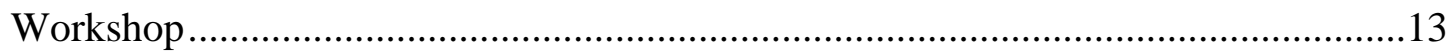

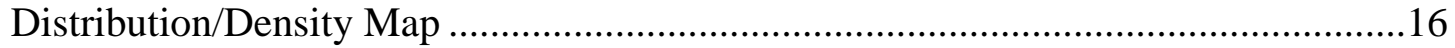

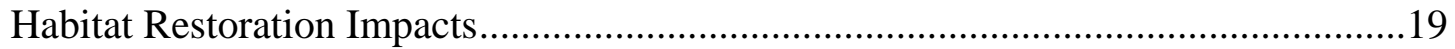

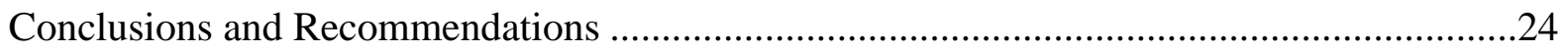

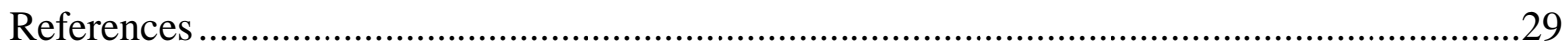

Appendix I: Nutria Eradication and Control Act of 2003 ...................................................34

Appendix II: Washington GAP Analysis Project Predicted Distribution Map .......................36

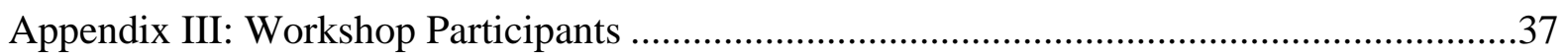

Appendix IV: Workshop Session \#1 Agenda ................................................................38

Appendix V: Workshop Session \#2 Action Items .........................................................39

Appendix VI: Example of a Distribution/Density Map Request for Information ..................41

Appendix VII: Example of a Preliminary Nutria Habitat Suitability Model ..........................43

Appendix VIII: GPS Study Plot Locations (Decimal Degrees) .........................................44

Appendix IX: Example of a Research Plot Inventory ...................................................45

Appendix X: Field Research Summary Data ..............................................................46

Appendix XI: Nutria Damage Questionnaire for USFWS Pacific Northwest Refuges...........47

Appendix XII: USFWS Questionnaire Cover Letter ......................................................49 


\section{List of Figures}

Figure 1: Nutria distribution in North America ................................................................1

Figure 2: Differences between nutria, beaver, and muskrat. A) Nutria-Myocastor coypus

B) Beaver - Castor canadensis C) Muskrat - Ondatra zibethicus

Figure 3: Common types of nutria damage. A) Herbivory leading to habitat destruction B) Burrowing leading to bank destabilization and erosion $\quad$ C) Parasite and pathogen transport leading to potential transmission to humans .............................................6

Figure 4: Relationship between number of nutria trapped and nutria pelt prices

Figure 5: Presentation during session \#1 of workshop 13

Figure 6: Regional map showing known nutria distribution and relative nutria densities (note that map is still in progress as information has not yet been reported for a large number of sub-watersheds; nutria are known to exist in the coastal regions of Washington)

Figure 7: Site configurations. A) Beaverton Creek Wetlands West B) Beaverton Creek Wetlands East C) Quatama D) Englewood Park (green lines delineate boundaries) ..20

Figure 8: Plot designs. A) Control plot B) Study plot .21

Figure 9: Close-up of nutria teeth marks on a damaged black hawthorne. 


\section{Abbreviations}

ANSTF Aquatic Nuisance Species Task Force

APHIS Animal Plant and Health Inspection Service

CLR Center for Lakes and Reservoirs

CNCP Coastwide Nutria Control Program

CVO Cascades Volcano Observatory

CWS Clean Water Services

EPA Environmental Protection Agency

GIS Geographic Information System

HSRRC Human Subjects Research Review Committee

HUC Hydrologic Unit Code

IANSP Idaho Aquatic Nuisance Species Plan

LDWF Louisiana Department of Wildlife and Fisheries

MDNR Maryland Department of Natural Resources

NIISS National Institute of Invasive Species Science

OANSMP Oregon Aquatic Nuisance Species Management Plan

ODFW Oregon Department of Fish and Wildlife

OAR Oregon Administrative Rules

PNWHF Pacific Northwest Hydrography Framework

PSU Portland State University

RCW Revised Code of Washington

USDA United States Department of Agriculture

USFWS United States Fish and Wildlife Service

USGS United States Geological Survey

VWREC Vancouver Water Resources Education Center

WAC Washington Administrative Code

WDFW Washington Department of Fish and Wildlife

WS Wildlife Services

WSANSMP Washington State Aquatic Nuisance Species Management Plan 


\section{Introduction}

The nutria (Myocastor coypus) is a large semi-aquatic mammal native to South America that has been introduced to numerous countries around the world, primarily for fur farming. Nutria fur farms in the United States originated as early as 1899, becoming more common in the 1930s. Nutria were initially imported to California, Oregon, Washington, Michigan, New Mexico, Louisiana, Ohio, and Utah for the fur farming industry (Carter and Leonard 2002). Various government agencies subsequently transported nutria to Alabama, Arkansas, Georgia, Kentucky, Maryland, Mississippi, Oklahoma, and Texas with the intent of using the species to control unwanted vegetation (LeBlanc 1994). When the nutria fur industry failed, the common practice was to simply release nutria from captivity. The species routinely escaped from the fur farms after natural disasters as well. Feral nutria populations have been reported throughout the country. However, populations in several states never established, became locally extinct, or were eradicated (Figure 1). Fifteen states are known to have stable or increasing nutria populations (Bounds 2000).

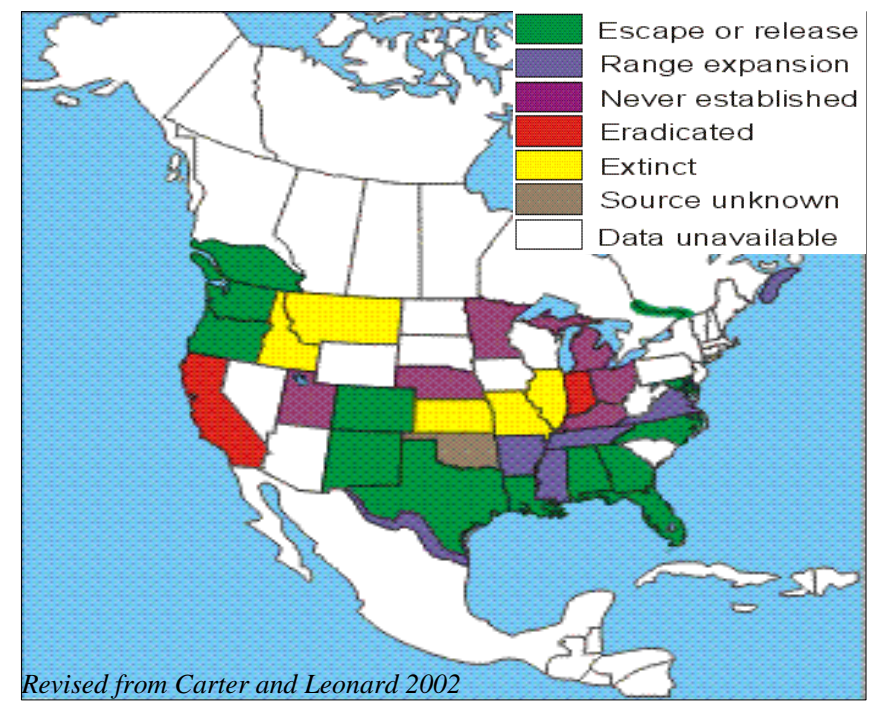

Figure 1: Nutria distribution in North America

\section{Identification}

Nutria are often confused with beavers or muskrats, but the species has a variety of distinct features (Figure 2). Nutria are much smaller than the beaver and much larger than the muskrat. The average adult size of the nutria is approximately ten to twenty pounds, and a mature adult measures about two feet in length (LeBlanc 1994). One of the most distinguishing features of the nutria is a thin, rounded, rat-like tail pointed at the tip, as opposed to the horizontally flattened tail of the beaver and the vertically flattened tail of the muskrat. The hind legs of the nutria are much longer than the front legs, giving the species a hunched appearance when on land. Nutria have prominent incisors that range in color from yellow to dark orange, and the color of the fur ranges from yellowish to dark brown (LeBlanc 1994). The nutria also has several adaptations for aquatic environments. These features include webbed hind feet, a 
A)

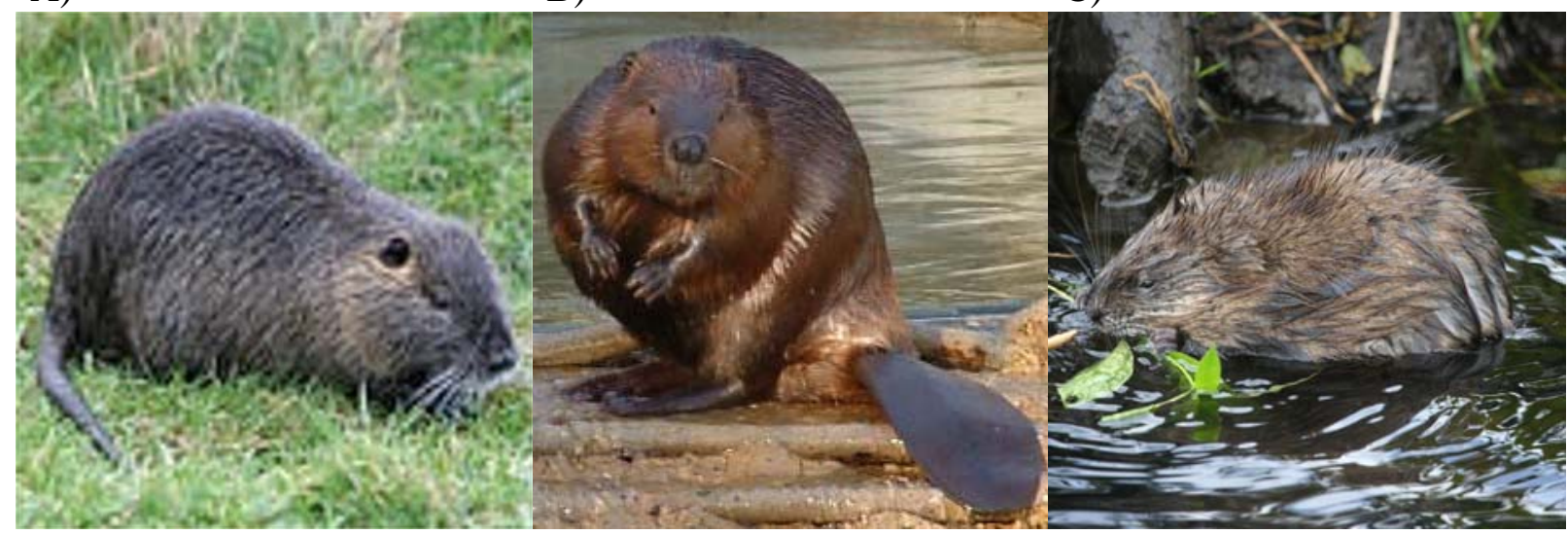

Figure 2: Differences between nutria, beaver, and muskrat. A) Nutria-Myocastor coypus B) Beaver - Castor canadensis C) Muskrat - Ondatra zibethicus

valvular nose and mouth, and eyes and ears set high on the head (LeBlanc 1994). These adaptations allow the nutria to move through aquatic environments efficiently and stay underwater for long periods of time.

\section{Habitat}

All significant nutria populations in the United States are located in wetland regions. The primary habitat type of nutria is freshwater marshes, but the species is also common in areas such as ponds, swamps, drainage canals, rivers, streams, and other systems with slow-flowing water (LeBlanc 1994). The main limiting factor for nutria distribution appears to be the severity of the winter season. Nutria are not adapted to extreme cold temperatures, and mortality rates during an unusually cold winter can climb to ninety percent after several consecutive days of subfreezing temperatures (Gosling et al. 1983). However, research has shown that the behavioral flexibility of nutria has allowed them to persist in regions previously thought to be too harsh for survival (Doncaster and Micol 1990).

Diet

Nutria are opportunistic herbivorous mammals that consume a large variety of aquatic, semi-aquatic, and terrestrial plants (Evans 1970). The species also feeds on crops and lawns that are located in close proximity to aquatic habitat. When feeding in the water, nutria often construct and utilize floating platforms made from aquatic vegetation. Nutria prefer the basal portions of plants and seasonally eat up to $25 \%$ of their body weight daily (Christen 1978). Nutria are also wasteful feeders, as estimates indicate that $90 \%$ of damaged plant material can remain unconsumed when foraging occurs on belowground roots and tubers (Taylor et al. 1997). 
Nutria diets have been shown to include all types of plant material, including leaves, stems, and even bark (Murua et al. 1981). When food is scarce in the winter, nutria have been documented to expand their diet and consume the roots and other underground parts of plants as well (Baroch and Hafner 2002). In natural environments, nutria have been shown to consume certain plant species significantly more than in proportion to availability, resulting in overutilization of these species (Borgnia et al. 2000). Research from other regions of the country has indicated that nutria diets change on a seasonal basis in conjunction with the availability of food sources (Abbas 1991, Wilsey et al. 1991).

Nutria are known to utilize different food sources in different regions of the world. In their natural range of Argentina, nutria diets consist of 40-60\% aquatic monocots, 30-35\% terrestrial monocots, and 0-15\% dicots. Spikerushes and duckweeds were the two most consumed species (Borgnia et al. 2000). In England, nutria fed on a large variety of crops such as cowbane and great water dock (Ellis 1963). Plants commonly consumed by nutria in Louisiana include cordgrasses, duckweeds, arrowheads, and bulrushes (Wilsey et al. 1991). Nutria diets in Maryland rely heavily on plant roots (Willner et al. 1979). In Oregon, nutria have been documented to feed on forty different species, with the most prominent species being willows, marsh purslane, and burr-reed (Wentz 1971).

\section{Life History}

Nutria generally survive less than three years in natural conditions, and estimated annual mortality rate ranges from 53\% (Chapman et al. 1978) to 74\% (Newson 1969). The mortality rate is dependent on many factors, but the main cause of death at nutria range edges is sustained freezing temperatures (Gosling et al. 1983). Outside of the native range, the few natural predators are carnivorous mammals such as foxes, bobcats, and coyotes, as well as large birds of prey (Oregon Department of Fish and Wildlife 2006). In urban areas, domestic dogs are also potential predators (Pers. Comm., Jacoby Carter, United States Geological Survey, National Wetlands Research Center). Nutria densities vary widely depending on habitat suitability. Individuals generally occupy a very small area, as daily cruising distances are typically less than six hundred feet (LeBlanc 1994). However, nutria travel much greater distances when establishing new territories and seeking new food sources. Individual nutria in Louisiana have been documented to travel up to 3.2 kilometers in a 24-hour period (Linscombe et al. 1981), and populations in eastern Europe extended 120 kilometers over a two-year period (Aliev 1968). 
Nutria live in dense vegetation during the warmer months and move into burrows when temperatures get colder. Burrows are generally located in vegetated banks near waterways, especially where slopes are greater than forty-five degrees (Peterson 1998). Nutria often construct extensive tunnel systems at multiple levels. These tunnel systems can be as long as one hundred and fifty feet, and underground chambers have been measured at three feet across (LeBlanc 1994). Burrows are usually located just above the water line. Nutria also build floating feeding platforms, which can reach a height of about three feet.

Nutria utilize a polygynous mating system and also have an organized social structure (Gosling and Baker 1987). Social groups contain approximately ten individuals made up of juveniles, subadults, and adults of both sexes. Each group typically has one dominant male that is larger than the other males (Guichon et al. 2003). The resident adult male is territorial and drives away young maturing males within the group and mature males from other social groups. Young males are often solitary as a result of this territorial behavior (Gosling 1977). Even though females are smaller than the males, females exhibit dominant behavior over the males except while mating. Finally, it has been found that male nutria participate with the females in nest defense (Warkentin 1968).

Nutria breed throughout the year, with reproductive peaks occurring in early summer, mid-autumn, and late winter. The gestation period is approximately one hundred and thirty days, and the average litter size is four to five offspring. However, in optimal habitats female nutria can produce a litter size of up to thirteen young (LeBlanc 1994). Newborn nutria are active immediately after birth and develop the ability to swim within a few hours. Once mature, individuals are about twenty-four inches long and typically weigh between ten and twenty pounds. Females are reproductively active by the age of four to six months and have the ability to produce nearly three litters every year (LeBlanc 1994). These reproductive traits highlight the capacity of the species to proliferate quickly, even when only a few individuals are initially present in a system. Based on conservative estimates of fecundity and mortality rates, one breeding pair in a system can result in a nutria population of more than 16,000 individuals after only three years, assuming that resources are not limited during that period.

Nutria are typically nocturnal creatures, especially when food sources are abundant. Peak activity is normally about midnight, but nutria also feed during the day when food supplies are more limited. Daytime feeding is also common in aquatic systems where human disturbance is 
infrequent or nonexistent (LeBlanc 1994). Research from Europe has also indicated that nutria exhibit diurnal behavior when they are being fed by humans (Meyer et al. 2005). Nutria have poor eyesight, so detection of danger occurs primarily by hearing and smelling. Despite their clumsy appearance, nutria possess surprising agility on land when frightened. Upon reaching the water, nutria hide in dense vegetation or stay submerged at the bottom for several minutes at a time. However, individuals can also become very aggressive when cornered (LeBlanc 1994). Diseases

Nutria populations are capable of carrying a large number of diseases, pathogens, and infections. For example, nutria have been found to be susceptible to rabies (Matouch et al. 1978), equine encephalomyelitis (Page et al. 1957), paratyphoid (Evans 1970), salmonellosis (Safarov and Kurbanova 1976), pappilomatosis (Jelinek et al. 1978), leptospirosis (Howerth et al. 1994), toxoplasmosis (Howerth et al. 1994), richettsia (Kovalev et al. 1978), coccidiosis (Michalski and Scheuring 1979), and sarcoporidiosis (Scheuring and Madej 1976). Further, more than a dozen types of microbial infections have been reported in nutria populations.

Nutria also host a wide variety of internal and external parasites. Nutria carry the nematode Strongyloides myopotami (Babero and Lee 1961), also known as 'nutria itch', resulting in a severe rash caused by larval roundworms that enter the skin of trappers who handle nutria fur (Little 1965). Other endoparasites discovered include eleven species of trematodes, twentyone cestode species, one acanthocephalan, and thirty-one nematode species (Babero and Lee 1961). External parasites of nutria include the chewing louse, fleas, and several tick species (Newson and Holmes 1968 and Willner 1982).

\section{Damage}

Most of the extensive damage caused by nutria is a direct result of feeding and burrowing. The feeding habits of nutria can lead to overexploitation of marsh and riparian vegetation (Figure 3A). "Eat outs" are areas in which aquatic vegetation damage is so extensive that the entire area has converted into an open-water system (Colona et al. 2003). Severe herbivory damage can lead to permanent loss of wetland structure. Nutria can also cause crop damage in areas where agricultural fields are located near aquatic habitat. Nutria burrow under and through water control structures such as levees, dikes, and dams, weakening the strength of these structures. Their burrows also cause significant weakening and collapsing of banks (Figure 3B) and road beds, especially in locations where the soil is saturated and the slope is greater than 
A)

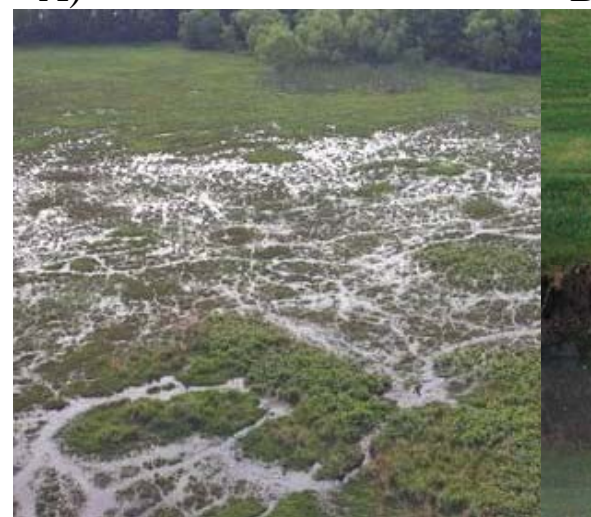

B)

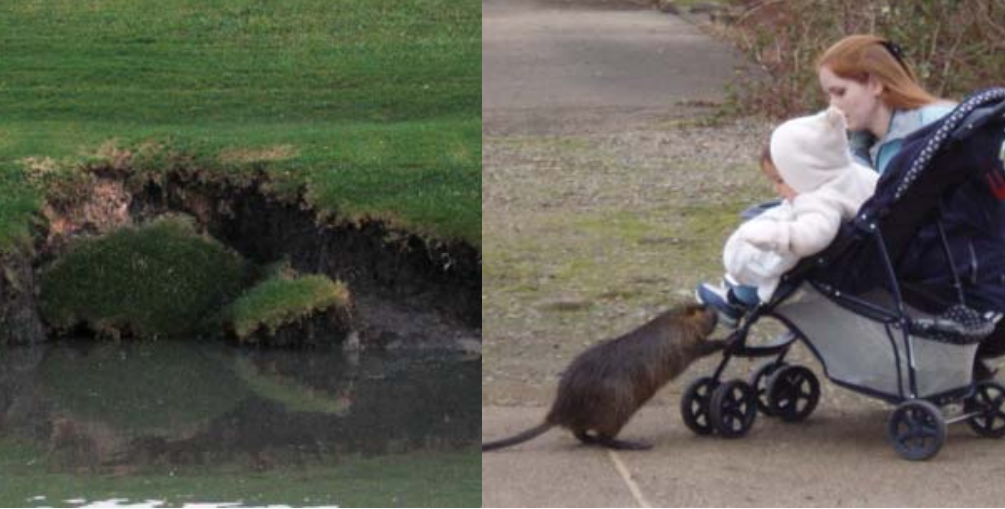

Figure 3: Common types of nutria damage. A) Herbivory leading to habitat destruction $\begin{array}{lll}B) & \text { Burrowing leading to bank destabilization and erosion } & \text { C) Parasite and }\end{array}$ pathogen transport leading to potential transmission to humans

forty-five degrees (Peterson 1998). Finally, nutria can carry a variety of diseases, pathogens, and parasites, some of which are transmittable to people, pets, and livestock (Figure 3C). Control and Eradication

Large-scale nutria control programs in the United States exist primarily in two states, Louisiana and Maryland. The Coastwide Nutria Control Program (CNCP), which is headed by the Louisiana Department of Wildlife and Fisheries (LDWF), offers a bounty of \$6 per tail to encourage private trappers to eliminate nutria. Incentive payments for the 2006-2007 trapping season totaled $\$ 1,878,415$. The stated goal of the program, which officially began in 2002 , is to annually harvest 400,000 nutria from coastal Louisiana to reduce nutria herbivory damage on marsh ecosystems. The CNCP has reported a decrease in damaged marsh area from an estimated 100,000 wetland acres in 1999 to an estimated 35,000 wetland acres presently (Louisiana Department of Wildlife and Fisheries 2007).

The state of Maryland implemented a nutria control program in an effort to preserve fragile marshes surrounding the Chesapeake Bay. The program is headed by the Maryland Department of Natural Resources (MDNR), United States Department of Agriculture (USDA), and several other partners. In 1999 a pilot project was initiated at the cost of \$4.2 million with the stated goals of estimating nutria populations and densities, monitoring nutria behavior and movement in response to trapping, and evaluating the reproductive response of nutria to trapping. After the completion of the pilot program in 2002, a large-scale trapping effort was implemented at the cost of $\$ 4$ million to test the feasibility of eradication (Maryland Department of Natural Resources 2006). The partnership group continues to eradicate local nutria 
populations through trapping efforts and remains optimistic that regional eradication is a future possibility.

The ongoing management programs in Louisiana and Maryland have spent millions of dollars in an effort to effectively manage their respective nutria populations. Most of the money has been federal dollars funneled through agency partnerships and private sources. The Nutria Eradication and Control Act of 2003 (Appendix I) allows the Secretary of the Interior to appropriate funds totaling up to \$6,000,000 to Maryland and Louisiana through the 2008 fiscal

year. A bill was introduced in the summer of 2007 that would reauthorize this public law beyond the 2008 fiscal year.

Attempts to eradicate feral nutria populations have taken place in several locations with varying degrees of success. In the United States, small nutria populations have been eradicated in California and Louisiana (Carter and Leonard 2002). In general, effective eradication projects must take place while nutria populations are still very small (Drake 2005). The most successful large-scale eradication program to date took place in Great Britain. An extensive trapping program during a five-year period in the 1980s reduced the number of adult females from 3,000 to approximately 20, and continued trapping efforts for five additional years eliminated the remaining population (Gosling and Baker 1987). Other eradication methods include shooting and poisoning, but trapping appears to be the most effective (Moutou 1997). It has also been shown that pre-baiting greatly improves results for all eradication methods (LeBlanc 1994).

\section{Nutria in the Pacific Northwest}

Regional nutria nuisance issues have developed recently as nutria populations continue to increase and expand into new geographical areas in both Oregon and Washington (Bounds 2000). Introduced populations in California, Idaho, and Montana did not survive, although feral nutria populations in California were not eradicated until 1978 (Deems and Pursley 1978). The Idaho Aquatic Nuisance Species Plan (IANSP) documents one nutria sighting at an unspecified location in 1991 (Idaho Invasive Species Council 2007), while Montana has identified nutria as a priority species with a high risk of invasion (Montana Fish, Wildlife, and Parks 2006). An increase in nutria damage complaints in Oregon and Washington coupled with the presence of significant nutria populations in urban areas have resulted in heightened awareness of nutria on a regional level. 


\section{History}

Nutria fur ranches were first introduced in Oregon and Washington in the late 1930s (Kinler 1992). More than 600 nutria fur farms were active in Oregon from the 1930s through the 1950s (Kuhn and Peloquin 1974). Trapping records indicate that feral nutria populations in Oregon and Washington were present on both sides of the Cascade Mountains in the 1940s (Witmer and Lewis 2001). Significant nutria populations were present in the Yakima Valley east of the Cascades until two consecutive harsh winter seasons in the late 1970s (Pers. Comm., George Brady [retired], Washington Department of Fish and Wildlife, Wildlife Program). Small nutria populations on tribal land in the Yakima Valley have been reported as recently as the early 1990s (Pers. Comm., Tracy Hames, Yakama Indian Nation, Wildlife Resource Management).

Nutria in the region were trapped mostly by accidental catch until the 1970s. A major increase in pelt prices in the late 1970s and early 1980s corresponded with large increases in annual trapping numbers (Figure 4). Trapping in Oregon reached a peak in 1977-1978 when 16,272 nutria were trapped according to state trapping reports. However, trapping numbers have decreased markedly recently as pelt prices have decreased (Figure 4). Data from other regions demonstrate a similar pattern (Louisiana Department of Wildlife and Fisheries 2007).

\section{Nutria Trapping Numbers in Oregon}

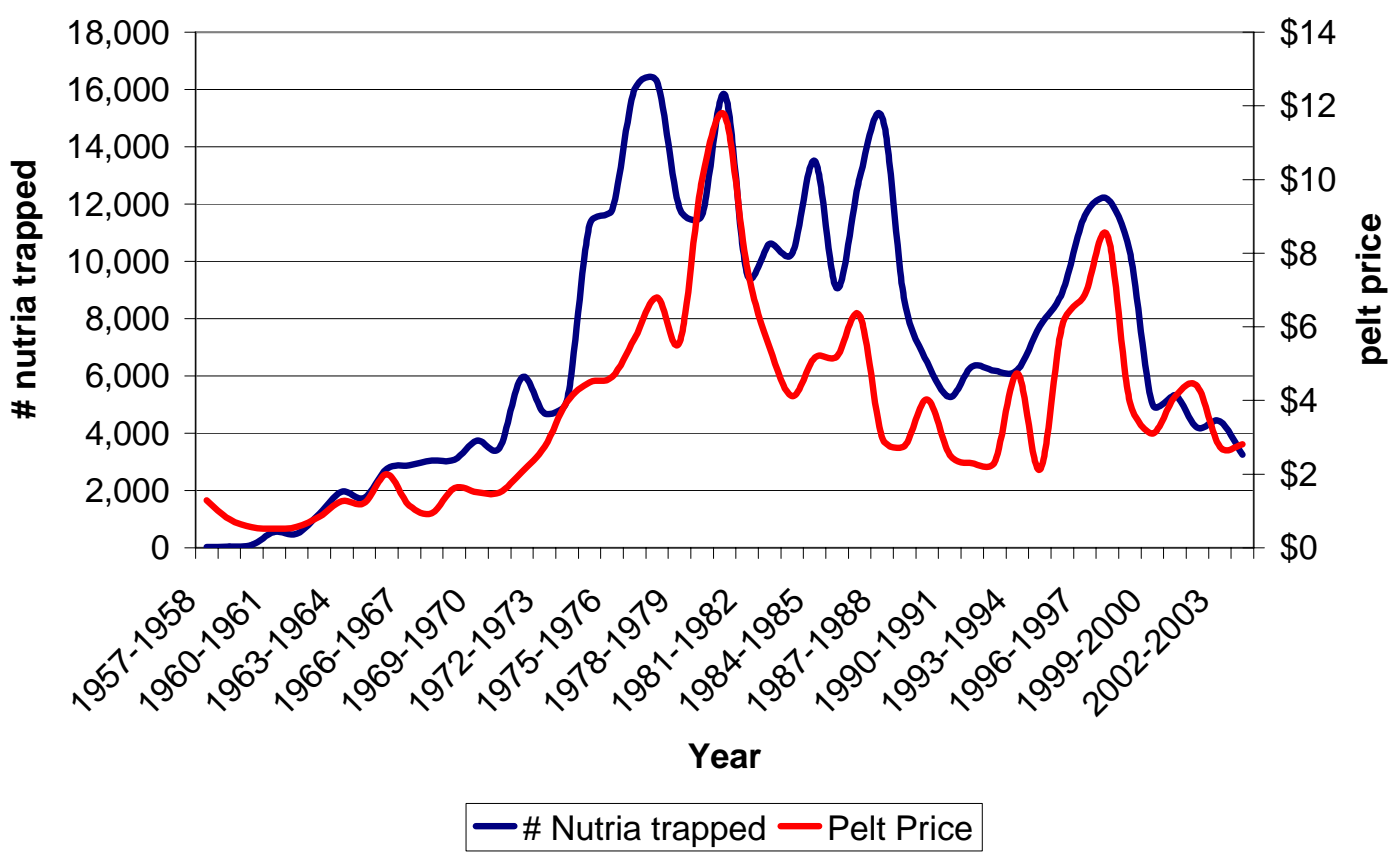

Figure 4: Relationship between number of nutria trapped and nutria pelt prices 
Legal Status

$\underline{\text { Idaho }}$

- The nutria is listed as a High Priority Species Not Currently Found in Idaho (IANSP)

$\underline{\text { Washington }}$

- The nutria is classified as a Prohibited Aquatic Animal Species (Washington Administrative Code [WAC] 220-12-090)

o All live-trapped nutria must be humanely terminated and not returned to the wild.

- A special trapping permit is required for the use of all traps other than live traps (Revised Code of Washington [RCW] 77.15.192, 77.15.194; WAC 232-12-142)

- It is unlawful to transport nutria anywhere within the state without a permit to do so (RCW 77.15.250; WAC 232-12-271)

\section{Oregon}

- The nutria is classified as a Prohibited Species (Oregon Administrative Rules [OAR] 635-056-0050)

o "Live [nutria] may not be imported, possessed, sold, purchased, exchanged or transported in the state."

- The nutria is classified as an Unprotected Mammal (OAR 635-050-0015 - 0210)

o There is no closed season for nutria trapping.

- All traps must meet certain legal specifications (OAR 635-050-0045)

Past Regional Research and Management Efforts

The following is a chronological list of past regional nutria management and research efforts that have been identified:

- Larrison, E.J. 1943. Feral coypus in the Pacific Northwest. The Murrelet 24:3-9.

- Peloquin, E.P. 1969. Growth and Reproduction of the Feral Nutria Myocastor coypus (Molina) Near Corvallis, Oregon. MS Thesis, Oregon State University.

- Wentz, W.A. 1971. The Impact of Nutria (Myocastor coypus) on Marsh Vegetation in the Willamette Valley, Oregon. MS Thesis, Oregon State University.

- Lester, D. 1997. Washington GAP Analysis Predicted Distribution Map - Nutria (Myocastor coypus). University of Washington, School of Aquatic and Fishery Sciences. (Appendix II) 
- Coulter, J. 2003. Duck, Geese, and Nutria Population and Damage Study. Clean Water Services Watershed Management Division Report.

- Link, Russel. 2004. Living with Wildlife - Nutria. Washington Department of Fish and Wildlife Report.

- Davison, M. and J. Bohannon. 2005. Nutria (Myocastor coypus) in Skagit County, WA: Background, Trapping Results, and Recommendations. Washington Department of Fish and Wildlife Report.

- Lemke, J.L. and C.R. Currens. 2006. Monitoring Protocols for the Inventory of Nutria Activity and Associated Streambank Erosion. ABR, Inc.—Environmental Research and Services Report contracted by Clean Water Services.

- Van, P.T. and F.A. Tkaczyk. 2006. Nutria of Lake Union (Washington) Project. Thesis Project, University of Washington, Wildlife Science.

- Frankel, D. 2007. The effects of coypu Myocastor coypus (nutria) on the water quality of Johnson Creek (South), Beaverton, Oregon. MS Thesis, Portland State University.

- Meyer, A. 2007. The Impacts of Nutria on Vegetation and Erosion in Oregon. MS Thesis, University of Colorado.

\section{Center for Lakes and Reservoirs at Portland State University Nutria Project}

The Center for Lakes and Reservoirs (CLR) at Portland State University (PSU) was established by the Oregon State Legislature to address lake management and invasive aquatic species issues in Oregon. In 2001, the Governor's office charged the CLR with developing the Oregon Aquatic Nuisance Species Management Plan (OANSMP). This plan is a comprehensive approach to management of aquatic invasive species in the state and includes prevention, outreach and education, detection, research, and management planning components.

The OANSMP classifies nutria as a management class 3 species, indicating that nutria “are established throughout Oregon with impacts but with no available or appropriate management techniques. [Nutria] warrant further evaluation and research to ascertain the potential control, and to prevent establishment in new waterbodies” (Hanson and Sytsma 2001). The Washington State Aquatic Nuisance Species Management Plan (WSANSMP) classifies nutria in a similar manner, stating that "[nutria] have been introduced, both intentionally and unintentionally into Washington and are well established in some areas... Management should be 
directed at limiting their spread into waters where they currently do not occur” (Meacham 2001). In accordance with the goals of the OANSMP and WSANSMP, in 2006 the CLR at PSU identified the following items as potential projects for regional nutria research and management:

- Completing a risk assessment for the Pacific Northwest.

- Mapping and tracking population spread and impacts.

- Studying habitat resistance/tolerance.

- Documenting agricultural impacts.

- Analyzing impacts to riparian and wetland restoration sites.

- Determining whether mitigation projects provide preferable habitat.

- Studying whether patchwork management contributes to the problem.

- Implementing trial eradication or control efforts.

- Developing novel management techniques for the Pacific Northwest. Purpose

After discussion and coordination with the United States Geological Survey (USGS), United States Fish and Wildlife Service (USFWS), ODFW, and CLR at PSU identified the following three key components regarding nutria management and research issues in the Pacific Northwest:

- Communication and coordination pertaining to nutria management and research.

- Accurate information on nutria distribution and density.

- Evaluation of economic and environmental nutria impacts at habitat restoration sites.

Coordinated regional communication

Nutria management in the Pacific Northwest occurs at a limited number of locations, and control efforts are conducted primarily at the local landowner level. There have been no efforts focused on limiting spread, controlling population size, or protecting prioritized habitat at a larger scale. Further, nutria have the ability to migrate through connected waterways into previously managed areas, making local management a very temporary solution. Effective longterm nutria management can only occur on a much larger scale. The cooperation of federal, state, and local agencies and landowners is vital in order to address the nutria issue at a regional level. Regional communication between these entities will increase awareness of the nutria issue, assist in determining the extent of the problem, help to identify areas of immediate concern, and lead to the development of potential management strategies. 


\section{$\underline{\text { Accurate distribution information }}$}

In order to facilitate coordinated regional efforts to control nutria impacts, accurate distribution information is crucial. Given the length of time since the initial introduction and establishment of nutria in the Pacific Northwest, existing maps are outdated and do not accurately reflect the current regional distribution of nutria populations. Recent reports of spread provide additional evidence that the regional distribution map of nutria populations must be improved and updated. Also, no regional estimates of relative nutria densities have been made to date. Mapping nutria populations in the Pacific Northwest is crucial for future regional management and research efforts. The development of a current map will help to establish the full extent of the invasion, provide information to aid in determining potential corridors for range expansion, and identify the locations at greatest risk for nutria damage. Finally, a nutria distribution/density map will aid in developing spatial management strategies.

\section{Evaluation of impacts on restoration sites}

While anecdotal and pictorial evidence of nutria disturbance on wetland and riparian restoration sites exists, there are few examples of efforts in the region to document the nature and extent of damage caused by nutria at these sites. Habitat restoration in the Pacific Northwest is considered crucial to the enhancement efforts of many endangered and listed species, so an assessment of ecological damage resulting from nutria activity is valuable information. In addition, a large investment in regional habitat restoration projects is made annually, so it is also important to assess whether or not these projects are cost-effective when nutria damage occurs. Assessments of ecological and economic damage caused by nutria will inform restoration managers about nutria impacts and aid them in developing strategies to minimize these impacts.

\section{Action Items}

The CLR at PSU coordinated with the United States Geological Survey (USGS), United States Fish and Wildlife Service (USFWS), Environmental Protection Agency (EPA), Oregon Department of Fish and Wildlife (ODFW), Washington Department of Fish and Wildlife (WDFW), and Clean Water Services (CWS) to address the three identified components by conducting the following activities:

- “Nutria Management in the Pacific Northwest” workshop - April 24-25, 2007

- Regional nutria distribution/density map - June 2007-present

- Research on nutria impacts on habitat restoration projects - April 2007-October 2007 


\section{Workshop}

The "Nutria Management in the Pacific Northwest" workshop was designed to address the following primary objectives:

- Provide information about the historical and current status of nutria on the national and regional scale; outline current and future nutria impacts.

- Facilitate communication and cooperation regarding nutria research on both the regional and national scale.

- Discuss regional nutria management strategies and coordination with a national nutria management plan.

The workshop was organized primarily by Trevor Sheffels, Mark Sytsma, and Robyn Draheim of the CLR at PSU, Paul Heimowitz of the USFWS, and Jacoby Carter of the USGS. The CLR at PSU, USFWS, and USGS were also the major funding partners, but additional funding was provided by the EPA, WDFW, and CWS. Registration for the workshop was open to all interested parties, but specific local, regional, and national entities were targeted for participation. Announcements were circulated throughout the Pacific Northwest to cities, universities, watershed councils, wildlife refuges, tribal organizations, surface water agencies, soil and water conservation districts, parks and recreation districts, diking and water control districts, state and federal environmental agencies, and relevant public and private companies. A complete list of all participating entities for the event can be found in Appendix III.

The workshop took place on April 24-25, 2007 in Vancouver, WA. The April $24^{\text {th }}$ session was held at the Vancouver Water Resources Education Center (VWREC) and the April $25^{\text {th }}$ session was held at the USGS Cascades Volcano Observatory (CVO). Both sessions were scheduled as all-day meetings. The first session (Figure 5) was attended by ninety individuals, which was

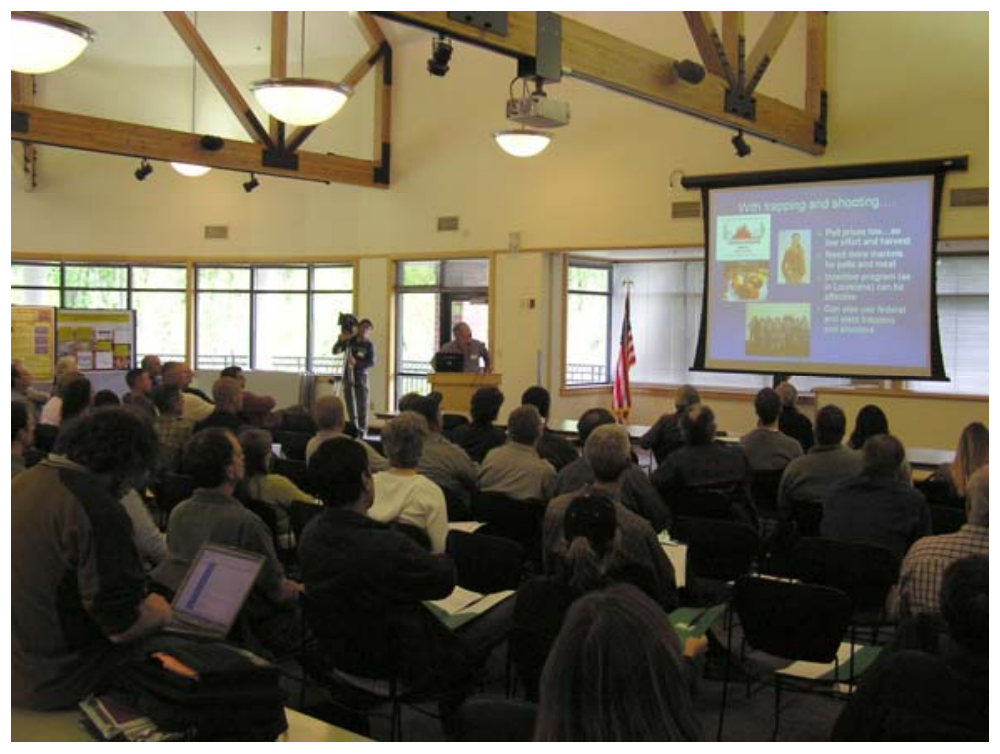

Figure 5: Presentation during session \#1 of workshop 
approximately the maximum capacity of the VWREC community room. The second session at the CVO was restricted to twenty individuals interested in implementing management changes.

Upon arrival on April $24^{\text {th }}$ at the VWREC, all participants were issued a registration packet with a complete agenda (Appendix IV) and various nutria informational materials for future reference. All attendees were encouraged to participate in the ten minute question and answer session following each presentation. A poster presentation area was also open for viewing throughout the day. Complete contact information was collected from each attendee for future communication.

The session began with a welcome and introduction from Mark Sytsma, Director of the CLR at PSU, who served as the moderator for the session. Representatives from the USFWS, ODFW, and WDFW stressed the significance of regional nutria research and management for their respective agencies. Dan Diggs, USFWS Pacific Region Assistant Regional Director of Fisheries, addressed the development of a national Aquatic Nuisance Species Task Force (ANSTF) nutria management plan and the importance of Pacific Northwest participation in developing this plan. Jim Gores, ODFW Invasive Species and Wildlife Integrity Coordinator, discussed the ODFW perspective on current challenges and future issues connected with nutria in the state of Oregon. Pamala Meacham, WDFW Assistant Aquatic Nuisance Species Coordinator, discussed the current expansion of nutria populations in the state of Washington and the importance of regional cooperation.

The second segment of the session focused on current nutria management and research activities being conducted on the national scale by the USGS, USDA, and Louisiana Department of Wildlife and Fisheries (LDWF). Jacoby Carter, USGS Invasive Species Program Nutria Research Coordinator, reviewed the history of nutria introduction and invasion, current research questions and efforts, and different strategies implemented by nutria control programs. Stephen Kendrot, Supervisory Wildlife Biologist for the Maryland branch of the USDA-Animal and Plant Health Inspection Service (APHIS)-Wildlife Services (WS), discussed the harmful impacts of nutria and Maryland's successful efforts to mitigate these impacts. He also discussed his role as the head of the national ANSTF nutria working group being developed to create a national nutria management plan. Gary Witmer, Research Wildlife Biologist for the USDA National Wildlife Research Center, discussed the advantages and disadvantages of available nutria eradication and management methods, current nutria control research, and future research needs. Edmond 
Mouton, LDWF Biologist Program Manager, summarized the history and development of the $\mathrm{CNCP}$ and the effectiveness of the program in preserving coastal marsh ecosystems in the state of Louisiana.

The third segment of the session focused on nutria management and research efforts at the regional and local level. Mike Davison, WDFW District Wildlife Biologist, summarized the Skagit County, Washington, nutria rapid response plan from a historical, current, and future perspective. Brian Vaughn, CWS Water Resources Project Coordinator, discussed nutria impacts on water quality and habitat restoration efforts in Washington County, Oregon, and his organization's nutria management and monitoring efforts. As part of the presentation, Debbie Frankel, graduate student at PSU in the Environmental Sciences and Resources Department, summarized her research regarding nutria impacts on local water quality. Justin Stevenson, Wildlife Disease Biologist for the Oregon branch of the USDA-APHIS-WS, discussed the possibility of diseases being transmitted from nutria to humans as a result of nutria populations in the Pacific Northwest living in close proximity to humans. Stevenson also summarized a future USDA-APHIS-WS study of the potential presence of Johne's disease in nutria in Tillamook County, Oregon.

Finally, the day concluded with a panel discussing nutria impacts on restoration efforts and communities throughout the Pacific Northwest. The panelists were Bruce Barbarasch of the Tualatin Hills Parks and Recreation District, Matt Cleland of the Washington branch of the USDA/APHIS/WS, Lauri Mullen of the City of Eugene Parks and Open Space Division, and Tim Esary of the City of Vancouver Greenways. All of the panelists summarized their respective nutria issues, which included the destruction of habitat restoration projects, the cost of nutria management efforts, nutria populations expanding into highly urbanized areas, and people regularly feeding nutria. Any nutria management strategies being employed were also discussed. The panelists then fielded a variety of questions from the audience and discussion continued in an interactive manner. Finally, the floor was opened to anyone who had any closing comments or thoughts. Before the session was adjourned, participants were encouraged to utilize the information provided in their registration packets and expand communication efforts regarding regional nutria issues. 
The purpose of the second session on April $25^{\text {th }}$ was to create an additional opportunity for communication and coordination between agencies and organizations committed to developing nutria management and research strategies for the Pacific Northwest. The meeting was restricted to twenty interested individuals who are in positions to implement nutria management and research strategies at the regional level. The session was co-mediated by Paul Heimowitz, USFWS Pacific Region Aquatic Nuisance Species Coordinator, and Mark Sytsma. The entire session was structured as an open forum designed for all members to actively participate in the discussions.

Stephen Kendrot started the session by speaking about the process used to develop the Chesapeake Bay nutria management plan and potential lessons to be learned from that process. The rest of the day was spent discussing nutria research and management priorities for the Pacific Northwest and how these priorities could be integrated in the national ANSTF nutria management plan. At the end of the session a list of action items and lead agencies was developed to encourage and guide future efforts (Appendix V).

Since the completion of the workshop, several cities and water districts in the region have become interested in implementing nutria management programs. Additionally, a variety of agencies and organizations have contacted the CLR at PSU concerning the development of an official regional nutria management plan. Communication and coordination is currently underway to assess the potential development of this plan. Finally, the national ANSTF nutria working group has formed, and the CLR at PSU is participating in this working group. Subcommittees are currently being formed, and the process for completing a national plan is expected to take approximately two years. The workshop and other nutria management and research efforts have ensured that the Pacific Northwest will be included in future nutria management and research activities at the national scale.

\section{Distribution/Density Map}

The regional nutria distribution/density map (Figure 6) has been created by utilizing various geographic information system (GIS) applications. All GIS work was completed using the ArcGIS 9.1 software. Watershed delineation information was obtained from the Pacific Northwest Hydrography Framework (PNWHF). The states of Oregon and Washington were divided into the $6^{\text {th }}$-field hydrologic unit code (HUC) boundaries delineated by the PNWHF, which is equivalent to the sub-watershed level. 


\section{Pacific Northwest Nutria Distribution/Density Map}

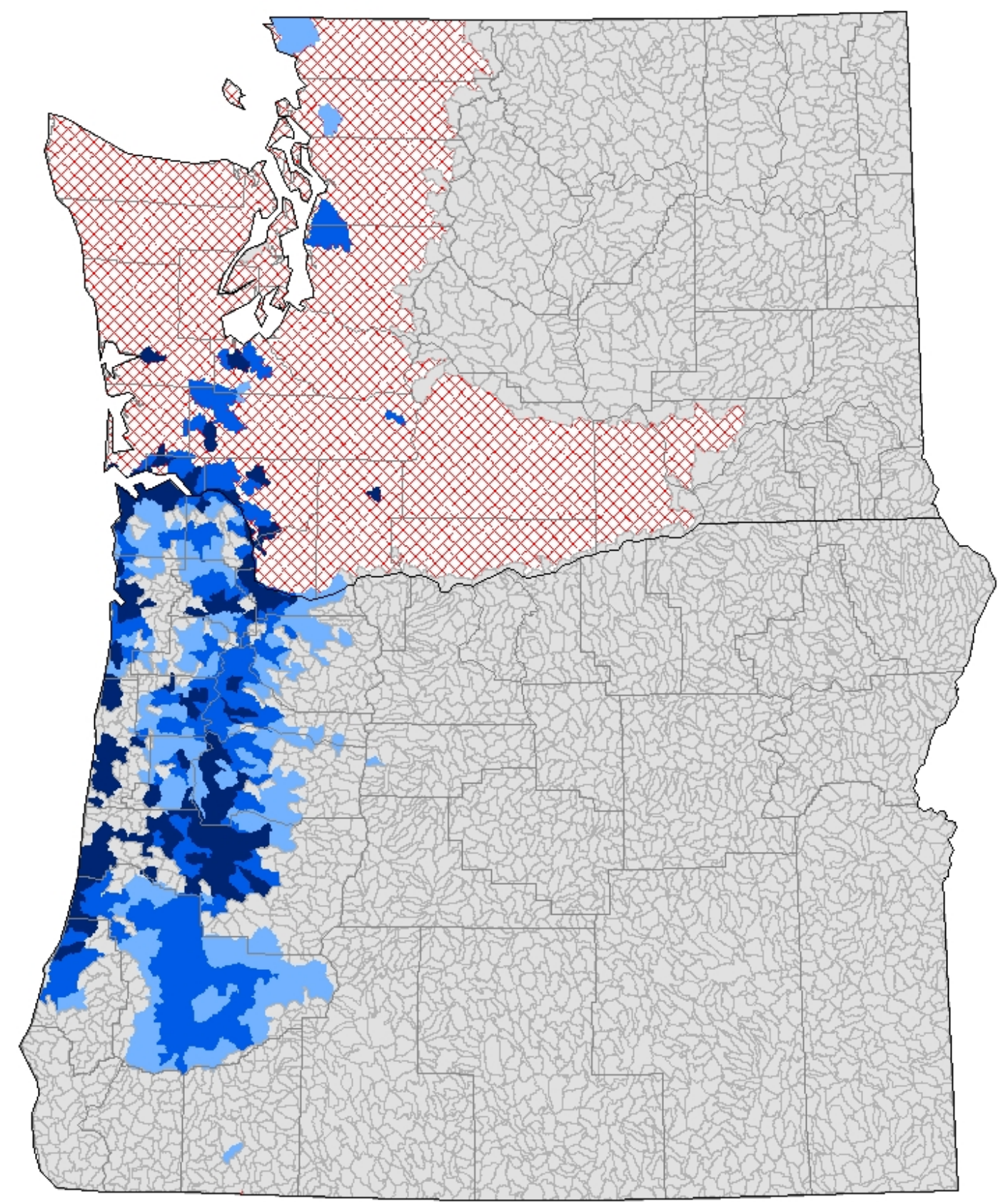

\section{Relative Nutria Density}

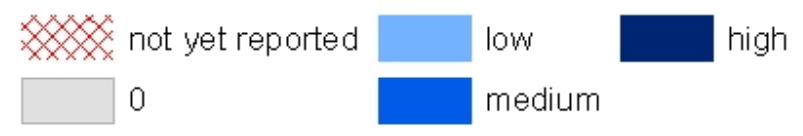

Figure 6: Regional map showing known nutria distribution and relative nutria densities (note that map is still in progress as information has not yet been reported for a large number of sub-watersheds; nutria populations are known to exist in the coastal regions of Washington) 
A series of maps were created based on the wildlife district boundaries of ODFW and WDFW respectively and incorporated into individualized requests for information (Appendix VI) for each district. Wildlife biologists were asked to estimate to the best of their ability the relative number of nutria in each sub-watershed for which they were responsible by choosing one of four predetermined categories. The predetermined relative nutria density categories were 0 individuals (zero density), 1-10 individuals (low density), 11-100 individuals (medium density), and >100 individuals (high density). Unfortunately, there is currently no standard protocol used by either ODFW or WDFW to document the presence or extent of nutria populations. All information received was based on the working knowledge of wildlife biologists who are very familiar with the watersheds in which they work. However, this left a large number of HUCs for which district biologists did not have enough information to estimate relative nutria densities.

It should be noted that nutria populations are known to exist in the coastal regions of both Oregon and Washington. Requests for information have been sent to USDA/APHIS/WS field personnel to obtain information about relative nutria densities in the sub-watersheds that have not yet been reported. Also, efforts will soon be underway to utilize external sources such as watershed councils, trappers, soil and water conservation districts, water resource inventory areas, wildlife control companies, golf courses, canoeing clubs, etc. After information has been collected for all sub-watersheds, ground-truthing efforts will be employed to verify the accuracy of the information used to create the final map.

The completion of the regional nutria distribution/density map will be very important for a variety of future nutria management and research efforts. In addition to identifying crucial management areas and migration corridors, the distribution/density map will also provide the foundation for developing future GIS research pertaining to nutria habitat suitability models. In fact, a group of researchers led by Dr. Thomas Stohlgren at the USGS Fort Collins Science Center: National Institute of Invasive Species Science (NIISS) is using the preliminary data from the Pacific Northwest to begin testing potential regional nutria habitat suitability models (Appendix VII). The NIISS will continue to coordinate with the USGS National Wetlands Research Center and the CLR at PSU as more regional distribution and density information becomes available. To date, complete nutria distribution and relative density information has been collected for more than 3,900 sub-watersheds of the total 4,600 sub-watersheds that comprise the regional map. 


\section{$\underline{\text { Habitat Restoration Impacts }}$}

Wetland management and restoration has historically been widely used as a method to slow the loss of wetland habitats (Johnson and Foote 1997). In order to manage wetlands effectively, it is important to understand the processes contributing to wetland degradation. Vertebrate herbivory is one of the processes that influences the structure and function of wetland communities (Kerbes et al. 1990). In addition to consumptive damage caused by wetland herbivores, these species also cause negative impacts by trampling, defecation, feeding platform construction, and trail formation (Johnson and Foote 1997). The known impacts of vertebrate herbivores in wetland systems include changes in plant biomass (Fuller et al. 1985), the alteration of species composition (Shaffer et al. 1990), and the modification of plant stand architecture (Lodge 1991).

Research from Maryland indicates that nutria feed heavily on plant roots, which changes soil structure and causes the transformation from wetlands to open water systems (Willner et al. 1979). Most of the research on nutria impacts in wetland ecosystems has been conducted in coastal Louisiana. Many of these studies have concluded that nutria herbivory significantly impacts plant diversity (Shaffer et al. 1990, Nyman et al. 1993), but other studies have refuted this conclusion (Smith 1988, Taylor and Grace 1995). Few studies regarding nutria impacts on plant communities have been conducted in the Pacific Northwest (Wentz 1971, Meyer 2007). All studies conclude that nutria herbivory significantly impacts aboveground vegetation biomass.

One area where research has been lacking is the impact of nutria herbivory on habitat restoration efforts. Research studies in Louisiana and Maryland have only addressed nutria feeding activity in natural wetland ecosystems where human activity does not occur on a regular basis. However, studies from Europe indicate that nutria can alter behavior and activity patterns when human influence is constant (Corriale et al. 2006, Meyer et al. 2005). Further, anecdotal reports suggest that nutria are damaging newly planted regional habitat restoration projects. For example, a riparian habitat restoration project in Vancouver, Washington, was decimated by nutria herbivory, resulting in a loss of \$400,000 (Pers. Comm., Tim Esary, City of Vancouver, Greenways Program). This suggests that new wetland restoration projects may be targeted by nutria, but this hypothesis has never been tested. The CLR at PSU developed a two-pronged research project to quantify nutria feeding activity on restoration plantings at selected riparian wetland restoration sites and document nutria herbivory damage on regional USFWS refuges. 


\section{Nutria Herbivory Damage on Habitat Restoration Projects in Washington County, Oregon}

All of the research sites were located in Washington County, Oregon, to build on the nutria management and research efforts of CWS, the wastewater and stormwater public utility for the Tualatin River Watershed. These efforts include regular nutria trapping and assessing nutria activity throughout the watershed. Site selection was based on the following criteria. All study sites were required to be riparian wetland systems, contain high densities of native trees and shrubs newly planted in the spring of 2007, and exhibit nutria activity in the recent past.

Four locations fit the criteria, and these four study sites were referred to as Beaverton Creek Wetlands West (Figure 7A), Beaverton Creek Wetlands East (Figure 7B), Quatama (Figure 7C), and Englewood Park (Figure 7D), all of which are current CWS riparian wetland restoration projects. Past indirect observations of nutria feeding activity suggested that nutria were responsible for an unknown degree of the observed damage at these sites. Native shrubs

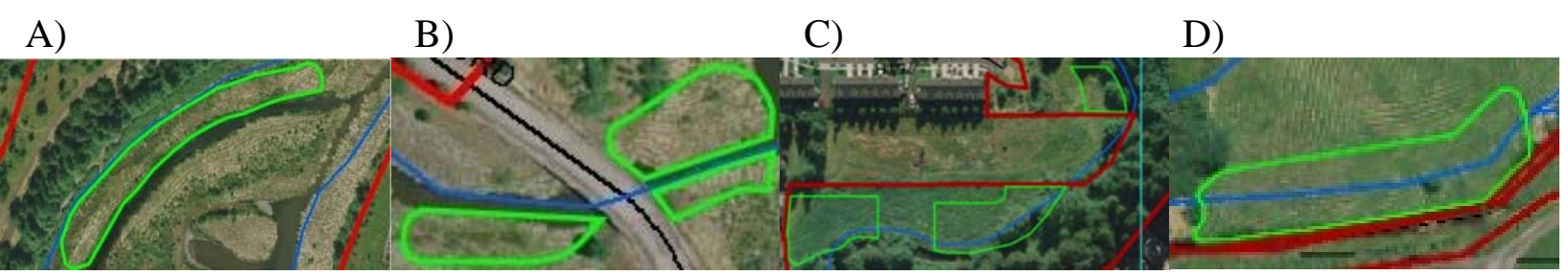

Figure 7: Site configurations. A) Beaverton Creek Wetlands West B) Beaverton Creek Wetlands East C) Quatama D) Englewood Park (green lines delineate boundaries)

and trees were planted within the riparian corridor at the four study sites in March-April 2007. These species were Oregon ash (Fraxinus latifolia), Douglas spirea (Spiraea douglasii), red osier dogwood (Cornus sericea), Pacific ninebark (Physocarpus capitatus), Sitka willow (Salix sitchensis), black twinberry (Lonicera involucrate), Pacific willow (Salix lucida), black cottonwood (Populus balsamifera), swamp rose (Rosa palustris), black hawthorne (Crataegus douglasii), red elderberry (Sambucus racemosa), and snowberry (Symphoricarpos albus).

Nutria trapping was ceased at three of the four study sites two months prior to the start of data collection. Trapping continued at Englewood Park, which served as the control between research sites. All four study sited were monitored during the two months prior to data collection to verify that nutria herbivory damage was not already occurring. Baseline data collection began following this two month period, which allowed restoration site plantings an opportunity to become established. 
The hypothesis that nutria are damaging restoration plantings in the Tualatin River watershed was tested by utilizing exclosure plots (Figure 8A) and corresponding study plots (Figure 8B) within the selected study sites. The exclosure plots served as the control within

A)

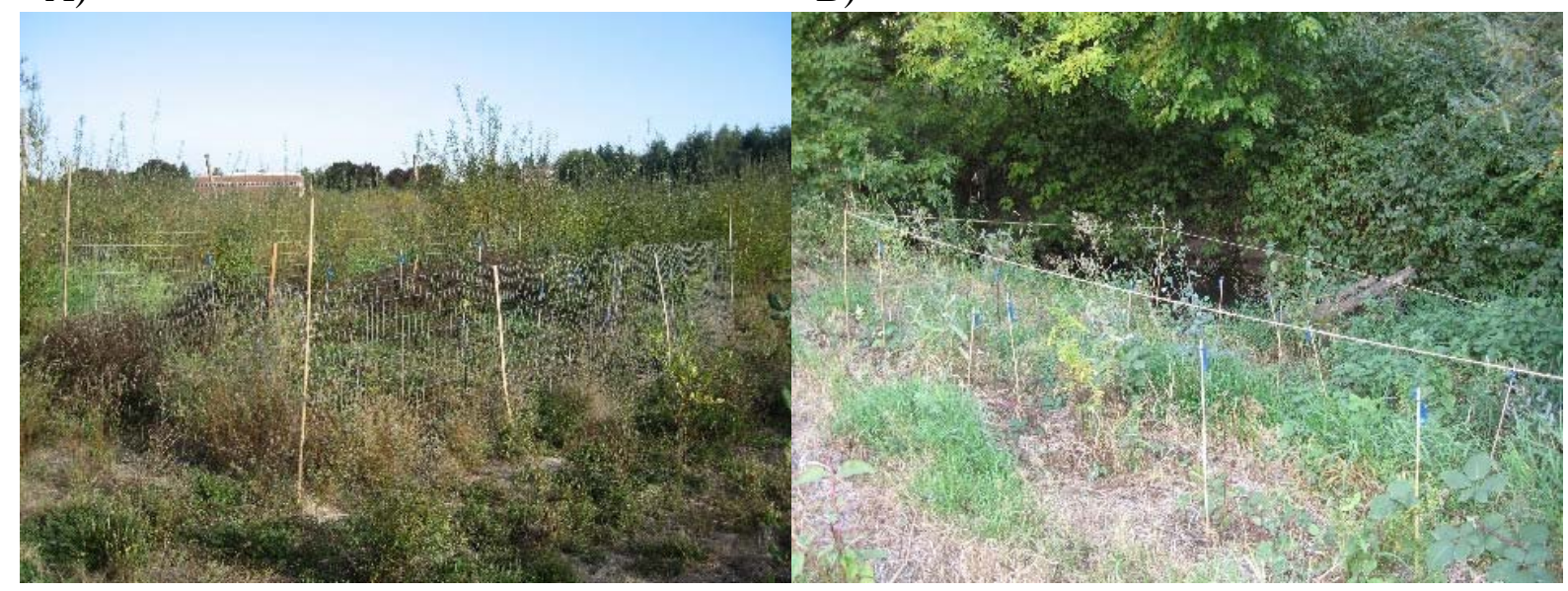

Figure 8: Plot designs. A) Control plot B) Study plot

sites. All control and study plots were located randomly within ten feet of the water edge using the 'iterate random points' function in the ArcGIS software (Appendix VIII). Plot location was adjusted slightly when dictated by physical characteristics. Exclosure construction followed methods used by Johnson and Foote (2005) and was modified to minimize environmental damage by using bamboo poles and a 2.5 foot stapled apron around the exclosure perimeter. The exclosure was designed to exclude nutria while allowing smaller species to move freely through the exclosure. Gates were constructed to allow entrance for inventory investigation and CWS invasive plant species control. Study plots were delineated by wrapping twine around the four bamboo corner poles at the height of approximately 4 feet. All exclosures and corresponding study plots were 20 feet (parallel to water) by 10 feet, for a total of 200 square feet. Finally, all control and study plots were located directly adjacent to the edge of the water where nutria damage generally occurs.

A detailed initial inventory of each exclosure and study plot was completed to identify the location and species of every planting within each plot. Stems were tagged to aid subsequent inventories. Data collection occurred for four months from July 1, 2007-October 31, 2007. The length of the study period was determined to be a sufficient amount of time to document any significant results. Anecdotal information from CWS suggested that nutria herbivory damage on 
habitat restoration sites is not significantly influenced by season, so temporal variation was not considered in the experimental design.

Study sites were visited twice each month from July 2007-October 2007. On each visit, an inventory (Appendix IX) of every plot was completed and analyzed. Stem density counts were used to document changes in each plot and potential differences between control plots and study plots. Observational data collection methods were used to limit environmental damage.

Thorough examinations on each visit verified that nutria were not entering control exclosures. Nutria population densities at each sight were qualitatively assessed by conducting night counts of nutria twice each month using night vision binoculars.

Very minimal nutria herbivory damage (Figure 9) occurred at two of the three study sites where nutria were not trapped. However, most of the restoration shrubs and trees that were lost resulted from desiccation during the summer months. Data (Appendix $X$ ) are not analyzed in detail in this report due to the fact that only three plantings were damaged as a result of nutria herbivory. This result could have been obtained for a variety of different reasons. For example, the density of local nutria populations in the broader study area seems to shift regularly, making it very difficult to predict where the most significant nutria herbivory damage on restoration sites will occur. The selected study sites had sustained visible nutria damage in the past resulting from dense nutria populations, but this was not the case during the course of the study period for unknown reasons. Also, invasive plant species, particularly reed canary grass (Phalaris arundinacea), at the study sites were heavily managed by CWS through regular mowing and chemical application. This high level of human activity and presence of herbicides throughout the study period may have deterred nutria from remaining at the study sites for an extended length of time.

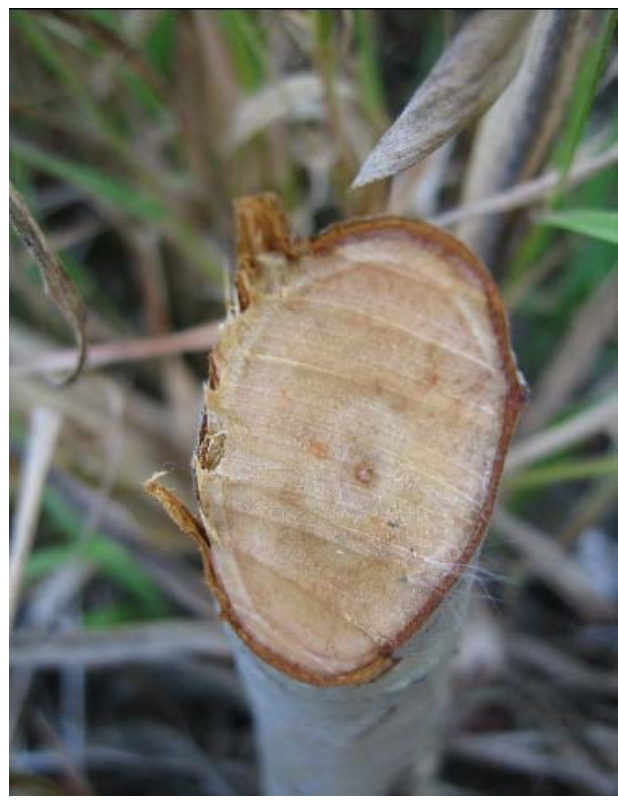

Figure 9: Close-up of nutria teeth marks on a damaged black hawthorne

Even though the hypothesis of the research was not supported by the data, the final month of the study did yield some interesting observations that are relevant for the development of future related management and research strategies. During the month of October, heavy rainfall 
caused stream levels throughout the study area to rise considerably in a short period of time. At Beaverton Creek Wetlands East, which exhibited the highest relative nutria density throughout the study period, this increased water level corresponded with a noticeable increase in nutria activity. Nutria feces were found regularly, but more importantly, numerous restoration trees and shrubs had been damaged as a result of herbivory. Teeth marks were measured to confirm that the damage was not caused by beaver, which are known to leave teeth marks greater than $1 / 8$ of an inch wide. Additionally, beaver generally completely consume branches measuring less than $3 / 4$ of an inch in diameter (Link 2004). Teeth marks less than $1 / 8$ of an inch wide and an abundance of chewed branches less than $3 / 4$ of an inch in diameter, coupled with large amounts of nutria feces in close proximity, confirmed that nutria are responsible for much of the damage on local CWS riparian wetland habitat restoration projects. Unfortunately, none of this herbivory occurred within the study plots where the damage could have been analyzed in detail. It should be noted that efforts will be made in the spring of 2008 to survey all first-year CWS restoration projects to determine whether this phenomenon is occurring in habitat restoration sites throughout the Tualatin River Watershed.

This observation of increased activity after an increase in water level suggests that local and/or regional nutria activity patterns may be dependent on specific environmental factors. While this is a fairly intuitive assumption, it could have implications for the regional management of nutria. For example, the increased water level may have created new riparian corridors within the study watershed through which nutria were able to easily migrate. This may also suggest that some nutria populations are seasonally isolated in marginal habitats when water levels are lower during the summer. The identification of seasonal migration corridors would be valuable information when determining priority areas for management. Increased water levels may also create easier access to streamside vegetation in some local habitats, allowing nutria to consume restoration plantings with considerably less effort in the winter months compared to the summer months. A potential opportunity for follow-up research could be to analyze relationships between water level and nutria activity at both the local and regional scales and explore potential management implications.

Questionnaire Regarding Nutria Herbivory Damage on Regional USFWS Refuges

Preliminary findings of the field research were used to inform a questionnaire-based questionnaire (Appendix XI) regarding nutria damage that was sent electronically to all regional 
USFWS refuge managers. The purpose of the questionnaire was to determine at each refuge whether nutria populations were present, whether nutria herbivory damage was being observed on habitat restoration projects, and whether any mitigation efforts were being implemented to limit nutria damage. The structure and questions of the questionnaire were guided by previous questionnaires produced by the CLR at PSU and reviewed by members of the USFWS Pacific Region Aquatic Invasive Species and Research Program and the USGS National Wetlands Research Center in order to develop an objective questionnaire. A cover letter was included to indicate the purpose of the questionnaire and confirm the consent of all participants (Appendix $X I I)$. Finally, the questionnaire and cover letter was submitted to the PSU Human Subjects Research Review Committee (HSRRC) and approved after minor revisions suggested by the HSRRC were completed.

Questionnaires were completed and returned by ten refuges, eight of which are located west of the Cascades Mountains, where all regional nutria populations are known to exist. Six of the eight refuges west of the Cascades reported the presence of nutria on their refuges. One of the refuges had sustained considerable herbivory damage on habitat restoration sites, but refuge personnel were unsure whether this damage had been caused by nutria or beaver. Even though extensive herbivory damage was only reported at one refuge, all refuges with significant nutria populations did report extensive nutria damage of another kind. Due to nutria burrowing activity, earthen levees used to control water flow within the refuges are being breached. In addition to erosion problems, the breaching of levees leads to either an excess or shortage of water being delivered to restoration project sites and other critical habitats being protected within the refuge systems. Unfortunately, none of the refuges are quantitatively assessing the economic impacts of nutria on their respective refuges even when monetary loss occurs. In terms of management, some refuges use opportunistic shooting in an attempt to control nutria population sizes, but no other nutria management or eradication efforts are currently being implemented by regional USFWS refuges.

\section{Conclusions and Recommendations}

This initial assessment of the current nutria situation in the Pacific Northwest conducted by the CLR at PSU has revealed that regional nutria problems are more extensive than previously realized. Nutria sightings have now been confirmed from the Canadian border (Pers. 
Comm., Craig Dolphin, Lummi Nation, Natural Resources Department) to near the southern border of Oregon (Pers. Comm., Mark Vargas, Oregon Department of Fish and Wildlife, Wildlife Division), confirming a larger range than was previously known. It was also found that the main nutria issues in the Pacific Northwest differ from issues in Louisiana and Maryland.

The most significant category of regional nutria damage appears to be the erosion of water control structures and natural banks resulting from burrowing, as opposed to herbivory damage in Louisiana and Maryland. This burrowing damage may be due to the fact that regional nutria populations exist in aquatic systems where sloped banks are abundant, such as rivers, streams, canals, and drainage ditches. In contrast, populations in Louisiana and Maryland subsist primarily in flat wetland ecosystems where nutria generally reside in dense vegetation and heavily utilize wetland vegetation as a food source.

Another unique situation in the Pacific Northwest is the high density of nutria populations in urban areas, increasing the potential for conflicts with humans. Nutria attacks have been reported in isolated cases, particularly when nutria become habituated to being fed by people. In addition to aggressive behavior, nutria can carry a variety of parasites and pathogens that could potentially be transmitted to humans and pets. It has also been confirmed that significant regional nutria herbivory damage does occur at some locations.

Fortunately, it has become evident that strong regional interest to address the nutria problem exists. Entities across the region are being negatively impacted by nutria, and these groups are eager to develop a solution. To date, small-scale nutria management efforts have been temporarily effective to some extent, but a permanent solution requires that the situation be addressed on a much larger scale. Due to the long period of time since the initial introduction and the current extent of regional populations, a long-term effort is likely required to address the nutria issue effectively. Further, temperatures and surface water distribution will likely shift in the coming years due to climate change, pointing to the need for adaptive management strategies.

The most immediate nutria management need is to develop an official regional nutria management plan with the focus of greatly reducing the amount of damage being caused by this invasive rodent and preventing further population growth and expansion. The effectiveness of initial management efforts will shed light on how to continue and whether regional eradication is a future possibility. Continued research and the development of coordinated management efforts at the regional scale are vital in order to bring the current regional nutria problem under control. 
The CLR at PSU has developed the following recommendations to help guide the process of determining how to most effectively manage nutria in the Pacific Northwest: Funding

First and foremost, future funding sources must be found in order to continue work on the regional nutria problem. Large-scale funding for the CLR at PSU nutria project expires at the end of the 2007 calendar year, and potential future funding opportunities are currently being explored. The project is currently supported by federal, state, and local agencies, and this mix of financial support has allowed for participation and input and multiple levels. A similar structure of financial support would be ideal in the future.

\section{Regional management plan}

The next step in the process is to write and implement an official regional nutria management plan. A large number of regional and local entities have expressed interest in participating in such a plan, and the CLR at PSU has agreed to draft a preliminary plan to be discussed by all participants. The development of this draft plan will be guided by previous invasive species management plans completed by the CLR at PSU. Also, the regional nutria management plan will parallel the national ANSTF nutria management plan currently being developed whenever appropriate.

After the completion of the draft plan, a stakeholder workshop will be held in the spring of 2008 to receive feedback and suggestions regarding the focus and elements of the final plan. Regardless of the final form of the management plan, it is imperative that an integrative and adaptive approach be utilized. The current practice of patchwork management at the local scale has proven to be ineffective at reducing nutria populations long-term. These efforts have demonstrated that local, state, and regional entities must work in harmony to manage nutria populations on a large scale.

Preliminary discussions have identified several potential elements to be included in the regional plan. For instance, the creation of an early detection rapid response plan will be important for limiting further spread of regional nutria populations. The development of the regional nutria distribution/density map has highlighted watersheds that may be at risk for invasion, and these areas need to be prepared for that potential event. Other elements include the development and implementation of best management practices for limiting nutria damage, the initiation of a pilot eradication program at watershed level, and suggestions for nutria research. 


\section{Research}

Regarding basic and applied nutria research in the Pacific Northwest, an infinite number of possibilities exist due to the fact that almost all nutria research has been conducted in other regions of the country. Applied research regarding nutria management is important because regional nutria impacts are unique from other areas of the country. For example, nutria burrowing activity and associated damage has not been studied to a great extent. Research on basic nutria biology and behavior is important because nutria populations in the Pacific Northwest appear to be unique. For example, nutria populations in urban areas may be adapting their activity patterns. While endless research opportunities exist, the following three research questions have been identified as priorities in order to better understand and manage nutria populations in the Pacific Northwest.

A central question regarding regional nutria management is whether or not nutria can be eradicated at the watershed level. A long-term pilot eradication project in selected watersheds could be undertaken to answer this question. An adaptive approach would be used, based on the environmental and other physical factors present in each study watershed. A multi-year assessment would shed light on whether eradication is feasible at the watershed level, and if not, demonstrate the best approach for managing regional nutria populations. Further, this pilot project could provide an opportunity to integrate other current nutria research questions. For example, test a variety of capture and lure techniques that are currently being researched and methods for detecting low levels of nutria populations.

Another research question is the potential association between climate change and regional nutria dispersal. It is widely assumed that sustained cold winter temperatures are the primary factor limiting population size and distribution. However, as the regional climate becomes more temperate due to global warming, the area of suitable nutria habitat in the Pacific Northwest may increase. For example, significant nutria populations were present east of the Cascade Mountains in the Yakima Valley until two consecutive harsh winter seasons in the late 1970s. No nutria sightings have been reported in the Yakima Valley since the early 1990s, but as mean winter temperatures continue to rise across the region, the likelihood of nutria reinhabiting the Yakima Valley and other similar habitats may increase.

Another potential research study is the dynamics of nutria-muskrat interactions. A variety of different sources have anecdotally reported that increases in nutria populations 
correspond with decreases in muskrat populations (Evans 1970). This phenomenon has also been reported in the Pacific Northwest. However, there has been no research to demonstrate that this association is a result of direct competition between nutria and muskrats. A research question focused on this association could be developed to determine whether species such as muskrat and river otter are being out-competed by nutria for resources. A related question is whether or not direct competition between nutria and beaver exists (Pers. Comm., Jacoby Carter, United States Geological Survey, National Wetlands Research Center).

Communication and coordination

As the process moves forward, continued coordination and communication at the regional scale will be crucial. Regarding coordination, the enforcement and synchronization of Oregon and Washington laws and regulations pertaining to nutria would eliminate much of the confusion about the legality of certain activities across the region. Also, the delegation of agency responsibilities would greatly speed up the entire process and ensure that sufficient resources are available to address the nutria problem at multiple levels. Regarding communication, an annual nutria management workshop should be held to provide a progress update to stakeholders, address any new problems, and discuss the refinement of management strategies. Finally, the CLR at PSU has created a nutria listserv, and utilizing this tool would aid in communication.

\section{Central database}

Another important element is the creation of a central database to record nutria damage and economic impacts associated with this damage. Infrastructure needed includes the development of protocols within the fish and wildlife agencies, wildlife control agencies, watershed districts, cities, etc. to document and report this damage information. Currently, there is virtually no information available that quantitatively assesses nutria damage either environmentally or economically. The ability to gather and broadcast this information would lead to increased exposure of the nutria issue and potential private and legislative interest in addressing the regional nutria problem.

Public involvement

As nutria issues increase, communities are becoming more aware of the regional nutria problem. It is important to involve these communities by encouraging public participation when 
possible and utilizing available public resources. A public education program could be used to educate people about general issues associated with nutria, the dangers associated with feeding nutria, and the potential for disease transmission. Ordinances requiring cities to post signage to further warn the public about the risks involved with feeding nutria may be a viable option.

Also, the creation of a phone hotline or interactive online map could be utilized to obtain further nutria distribution information from the public. Finally, it is important to address the concerns of public minority that feels nutria should be left alone. It is vital to stress that the nutria is an invasive species that can both directly and indirectly harm the native flora and fauna of the Pacific Northwest.

\section{References}

Aliev, F.F. 1968. Contribution to the study of nutria-migrations (Myocastor coypus). Saugetierkundliche Mitteilungen 16:301-303.

Babero, B.B. and J.W. Lee. 1961. Studies on the helminthes of nutria (Myocastor coypus) in Louisiana with check list of other worm parasites from this host. The Journal of Parasitology 47:378-390.

Baroch, J. and M. Hafner. 2002. Nutria (Myocastor coypus) in Louisiana. Genesis Laboratories, Inc., Report for Louisiana Department of Wildlife and Fisheries. 155 pp.

Bounds, D.L. 2000. Nutria: an invasive species of national concern. Wetland Journal 12:9-16.

Bounds, D.L.,T.A. Mollett, and M.H. Sherfy. 2001. The nutria nuisance in Maryland and the search for solutions. Aquatic Nuisance Species Digest 4(3):25-31.

Carter, J. and B.P. Leonard. 2002. A review of the literature on the worldwide distribution, spread of, and efforts to eradicate the coypu (Myocastor coypus). Wildlife Society Bulletin 30: 162-175.

Chapman, J.A., G.R. Willner, K.R. Dixon and D. Pursley. 1978. Differential survival rates among leg-trapped and live-trapped nutria. Journal of Wildlife Management 42:926-928.

Christen, M.F. 1978. Evalucion nutritive de cuatro dietas monoespecificas en la alimentacion del coipo (Myocastor coypus). Tesis Faculitad de Medicina Veterinaria, Universidad Austral de Chile, Valdivia.

Colona, R., R. Farrar, S. Kendrot, J. McKnight, T. Mollett, D. Murphy, L. Olsen, K. Sullivan. 2003. Nutria (Myocastor coypus) in the Chesapeake Bay: A Draft Bay-Wide Management Plan. pp. 1-24.

Corriale, M.J. S.M Arias, R.F. Bó, and G. Porini. 2006. Habitat-use patterns of the coypu Myocastor coypus in an urban wetland of its original distribution. Acta Theriologica 51(3):295-302. 
Coulter, J. 2003. Duck, Geese, and Nutria Population and Damage Study. Clean Water Services Watershed Management Division Report.

Davison, M., and J. Bohannon. 2005. Nutria (Myocastor coypus) in Skagit County, WA: Background, Trapping Results, and Recommendations. Washington Department of Fish and Wildlife.

Deems, E.F. and D.Pursley. 1978. North American furbearers: their management, research and harvest status in 1976: International Association of Fish and Wildlife Agencies in cooperation with the Maryland Department of Natural Resources-Wildlife Administration: College Park, University of Maryland, University Press, 165 pp.

Doncaster, C.P. and T. Micol. 1990. Response by coypus to catastrophic events of cold and flooding. Holarctic Ecology 13:98-104

Drake, J.M. 2005. Risk analysis for invasive species and emerging infectious diseases: concepts and applications. American Midland Naturalist 153:4-19.

Evans, J. 1970. About nutria and their control. United States Bureau of Sport Fisheries and Wildlife, Denver Wildlife Research Center, Denver, Colorado, USA.

Frankel, D. 2007. The effects of coypu Myocastor coypus (nutria) on the water quality of Johnson Creek (South), Beaverton, Oregon. Master of Science Thesis, Portland State University, Environmental Sciences and Resources Department.

Fuller, D.A., C.E. Sasser, W.B. Johnson, and J.G. Gosselink. 1985. The effects of herbivory on vegetation on islands in Atchafalaya Bay Louisiana. Wetlands 4:105-114.

Gosling, L.M. 1977. Coypu. pp. 256-265, in The Handbook of British mammals. Second Edition (G.B. Corbet and H.N. Southern, eds). Blackwell Scientific Press, Oxford 520 pp.

Gosling, L.M. and S.J. Baker. 1987. Planning and monitoring an attempt to eradicate coypus from Britain. Symposium for Zoological Society of London 58:99-113.

Gosling, L.M., S.J. Baker, and J.R. Skinner. 1983. A Simulation Approach to Investigating the Response of a Coypu Population to Climatic Variation. European Plant Protection Organization Bulletin 13(2): 183-192.

Guichon, M.L., C.P. Doncaster and M.H. Cassini. 2003. Population structure of coypus (Myocastor coypus) in their region of origin and comparison with introduced populations. Journal of Zoology, London 261:265-272.

Hanson, E. and M. Sytsma. 2001. Oregon Aquatic Nuisance Species Management Plan. Center for Lakes and Reservoirs, Portland State University. 95 pp.

Howerth E.W., A.J. Reeves, M.R. McElveen and F.W. Austin. 1994. Survey for selected diseases in nutria (M. coypus) from Louisiana. Journal of Wildlife Diseases 30:450-453.

Idaho Invasive Species Council Technical Committee. 2007. Idaho Aquatic Nuisance Species Plan. Prepared for Governor C.L. "Butch” Otter and Idaho Invasive Species Council. 139 pp.

Jelinek, P., L. Valicek, B. Smid and R. Halouzka. 1978. Determination of papilomatosis in the coypus (Myocastor coypus). Veterinarni Medicina (Prague) 23:113-119. 
Johnson, L.A. and A.L. Foote. 2005. Effects of managed impoundments and herbivory on wetland plant production and stand structure. Wetlands 25(1):38-50.

Johnson, L.A. and A.L. Foote. 1997. Vertebrate herbivory in managed coastal wetlands: a manipulative experiment. Aquatic Botany 59:17-32.

Kerbes, R.H., P.M. Kotanen, and R.L. Jeffries. 1990. Destruction of wetland habitats by lesser snow geese: a keystone species on the west coast of Hudson Bay. Journal of Applied Ecology 27:242-258.

Kinler, N.W. 1992. Historical and biological overview. pp. 8-14 in Nutria and muskrat management symposium. Louisiana Cooperative Extension Service, 8-9 October 1992, Baton Rouge, USA.

Kovalev, V.L., R.K. Andreeva and S.N. Stepanova. 1978. Wild animals as reservoirs of Chlamydia. Izdatel'stvo Nauka 1978:139-143.

Kuhn, L.W. and E.P. Peloquin. 1974. Oregon's nutria problem. Proceedings of the Vertebrate Pest Conference 6:101-105

Larrison, E.J. 1943. Feral coypus in the Pacific Northwest. The Murrelet 24:3-9.

LeBlanc, D.J. 1994. Nutria. Animal and Plant Health Inspection Service. Animal Damage Control, Port Allen, LA. B71-B80.

Lemke, J.L. and C.R. Currens. 2006. Monitoring Protocols for the Inventory of Nutria Activity and Associated Streambank Erosion. ABR, Inc.-Environmental Research and Services Report contracted by Clean Water Services.

Lester, Dave. 1997. Volume 3: Terrestrial Mammals of Washington State: Location data and predicted distributions. Washington Cooperative Fish and Wildlife Research Unit. 304 pp.

Link, Russel. 2004. Living with Wildlife - Nutria/Beaver. Washington Department of Fish and Wildlife Report.

Linscombe, G., N. Kinler and V. Wright. 1981. Nutria population density and vegetative changes in brackish marsh in coastal Louisiana. Pages 129-141 in (J.A. Chapman and D. Pursley, eds.) Proceedings of the Worldwide Furbearer Conference 1:1-651.

Little, M.D. 1965. Dermatitis in a human volunteer infected with Strongyloides of nutria and raccoon. American Journal of Tropical Medicine \& Hygiene 14:1007-1009.

Lodge, D.M. 1991. Herbivory on freshwater macrophytes. Aquatic Botany 41:195-224.

Louisiana Department of Wildlife and Fisheries. 2007. Nutria Harvest Distribution 2006-2007 and A Survey of Nutria Herbivory Damage in Coastal Louisiana in 2007. <http://nutria.com/uploads/0607Finalreport.pdf>. 10/16/2007.

Maryland Department of Natural Resources. 2006. Maryland Marsh Restoration/Nutria Project Partnership. <http://www.dnr.state.md.us/wildlife/invnutriaproj.asp>. 10/16/2007.

Matouch, O., J. Donsek and O. Ondracek. 1978. Vyskyt vztekliny u nutrie. [ Rabies in the nutria.] Veterinarstvi 28:549. 
Meacham, Pamala. 2001. Washington State Aquatic Nuisance Species Management Plan. Washington Department of Fish and Wildlife for the Washington Aquatic Nuisance Species Coordinating Committee. 196 pp.

Meyer, A. 2007. The Impacts of Nutria on Vegetation and Erosion in Oregon. Master of Science Thesis, University of Colorado.

Meyer, J., N. Klemann, and S. Halle. 2005. Diurnal activity patterns of coypu in an urban habitat. Acta Theriologica 50(2):207-211.

Michalski, Z. and W. Scheuring. 1979. Kokcydioza jelit u nutrii. [ Coccidiosis of intestine in the nutria.] Wiadomosci Parazytologiczne 25:99-104.

Montana Fish, Wildlife, and Parks. 2006. Aquatic Nuisance Species - Mammals: Nutria. <http://fwp.mt.gov/fishing/fishingmontana/ans/Mammals.html>. 11/16/2006.

Moutou, F. 1997. Aquatic and semi-aquatic mammals introduced into France. Risks and Consequences. Bulletin. Francais De La Peche Et De La Pisciculture 344/345:133-139. (abstract in English).

Newson, R.M. 1969. Population dynamics of the coypu (Myocastor coypus) in Eastern England. Pages 203-204 in (K. Petrsewicz and L. Ryskowski, eds.) Energy flows through small mammal populations. Polish Scientific Publishers, Warsaw. 350 pp.

Newson, R.M. and R.G. Holmes. 1968. Some ectoparasites of the coypu (Myocastor coypus) in Eastern England. Journal of Animal Ecology 37:471-481.

Nyman, J.A., R.H. Chabreck and N.W. Kinler. 1993. Some effects of herbivory and 30 years of weir management on emergent vegetation in brackish marsh. Wetlands 13:165-175.

Oregon Department of Fish and Wildlife. 2006. Nonnative wildlife: nutria (Myocastor coypus). <http://www.dfw.state.or.us/springfield/nonnative.html>. 11/14/2006.

Oregon Secretary of State. 2007. Oregon Administrative Rules. $<$ http://arcweb.sos.state.or.us/banners/rules.htm>. 10/23/2007

Page, C.A., V.T. Harris and J. Durand. 1957. A survey of virus in nutria. Southwest Louisiana Journal 1:207-210.

Peloquin, E.P. 1969. Growth and Reproduction of the Feral Nutria Myocastor coypus (Molina) Near Corvallis, Oregon. Master of Science Thesis, Oregon State University.

Peterson, R. 1998. Beaver, Muskrat and Nutria on Small Woodlands. Woodland Fish and Wildlife, MISC0196:1-8.

Safarov, Y.B. and M.A. Kurbanova. 1976. Influence of some therapeutic substances on the immulogical response of nutria (Myocastor coypus) (antibiotics and nitrofurans in relation to salmonellosis). Veterinariya (Moscow) 11:65-66 (in Russian).

Scheuring, W. and J.A. Madej. 1976. Sarcosporidiosis in nutria. Medycyna Weterynaryjna 32:437-438. 
Shaffer, G.P., C.E. Sasser, J.G. Gosselink and M. Rejmanek. 1990. A decade of vegetation dynamics in the emergent Atchafalaya delta, Louisiana. Bulletin of the Ecological Society of America (Supplement):322-323 (Abstract).

Smith, L. M. 1988. Lack of herbivory in playa wetlands. Wetlands 8:193-197.

Taylor, K.L. and J.B. Grace. 1995. The effects of vertebrate herbivory on plant community structure in the coastal marshes of the Pearl River, Louisiana, USA. Wetlands 15:68-73.

Taylor, K.L., J.B. Grace and B.D. Marx. 1997. The effects of herbivory on neighbor interactions along a coastal marsh gradient. American Journal of Botany 84:709-715.

Van, P.T. and F.A. Tkaczyk. 2006. Nutria of Lake Union (Washington) Project. Thesis Project, University of Washington, Wildlife Science.

Warkentin, M.J. 1968. Observations on the behavior and ecology of the nutria on Louisiana. Tulane Studies in Zoology and Botany 15:10-17.

Washington State Legislature. 2007. Revised Code of Washington. $<$ http://apps.leg.wa.gov/rcw/>. 10/23/2007

Washington State Legislature. 2007. Washington Administrative Code. $<$ http://apps.leg.wa.gov/wac/>. 10/23/2007.

Wentz, W.A. 1971. The Impact of Nutria (Myocastor coypus) on Marsh Vegetation in the Willamette Valley, Oregon. Master of Science Thesis, Oregon State University.

Willner, G.R. 1982. Nutria:Myocastor coypus. Pages. 1059-1076 in Wild mammals of North America (J.A. Chapman and G.A. Feldhammer, eds.) The John Hopkins University Press, Baltimore $1147 \mathrm{pp}$.

Willner, G.R., J.A. Chapman and D. Pursley. 1979. Reproduction, physiological responses, food habits and abundance of nutria on Maryland marshes. Wildlife Monographs 65:1-43.

Witmer, G.W. and J.C. Lewis. 2001. Introduced Wildlife in Oregon and Washington. USDA National Wildlife Research Center - Staff Publications. 23 pp. 


\section{Appendix I: Nutria Eradication and Control Act of 2003}

PUBLIC LAW 108-16-APR. 23, 2003

Public Law 108-16

\section{8th Congress}

\section{An Act}

To provide for the eradication and control of nutria in Maryland and Louisiana.
Be it enacted by the Senate and House of Representatives of the United States of America in Congress assembled,

SECTION 1. SHORT TITLE.

This Act may be cited as the "Nutria Eradication and Control

Apr. 23, 2003

Nutria

Eradication and

Control Act of 2003 . Act of 2003".

\section{SEC. 2. FINDINGS AND PURPOSES.}

(a) Findings.-The Congress finds the following:

(1) Wetlands and tidal marshes of the Chesapeake Bay and in Louisiana provide significant cultural, economic, and ecological benefits to the Nation.

(2) The South American nutria (Myocastor coypus) is directly contributing to substantial marsh loss in Maryland and Louisiana on Federal, State, and private land.

(3) Traditional harvest methods to control or eradicate nutria have failed in Maryland and have had limited success in the eradication of nutria in Louisiana. Consequently, marsh loss is accelerating.

(4) The nutria eradication and control pilot program authorized by Public Law 105-322 is to develop new and effective methods for eradication of nutria.

(b) PURPOSE.-The purpose of this Act is to authorize the Secretary of the Interior to provide financial assistance to the State of Maryland and the State of Louisiana for a program to implement measures to eradicate or control nutria and restore marshland damaged by nutria.

\section{SEC. 3. NUTRIA ERADICATION PROGRAM.}

(a) GRANT AUTHORITY.-The Secretary of the Interior (in this Act referred to as the "Secretary"), subject to the availability of appropriations, may provide financial assistance to the State of Maryland and the State of Louisiana for a program to implement measures to eradicate or control nutria and restore marshland damaged by nutria.

(b) GOALS.-The goals of the program shall be to-

(1) eradicate nutria in Maryland;

(2) eradicate or control nutria in Louisiana and other States; and

(3) restore marshland damaged by nutria.

(c) ACTIVITIES.-In the State of Maryland, the Secretary shall require that the program consist of management, research, and 
public education activities carried out in accordance with the document published by the United States Fish and Wildlife Service entitled "Eradication Strategies for Nutria in the Chesapeake and Delaware Bay Watersheds", dated March 2002.

(d) COST SHARING.-

(1) FEDERAL SHARE.-The Federal share of the costs of the program may not exceed 75 percent of the total costs of the program.

(2) IN-KIND CONTRIBUTIONS.-The non-Federal share of the costs of the program may be provided in the form of in-kind contributions of materials or services.

(e) LIMITATION ON ADMINISTRATIVE EXPENSES.-Not more than 5 percent of financial assistance provided by the Secretary under this section may be used for administrative expenses.

(f) AUTHORIZATION OF APPROPRIATIONS.-For financial assistance under this section, there is authorized to be appropriated to the Secretary $\$ 4,000,000$ for the State of Maryland program and $\$ 2,000,000$ for the State of Louisiana program for each of fiscal years 2004, 2005, 2006, 2007, and 2008.

Deadline.

SEC. 4. REPORT.

No later than 6 months after the date of the enactment of this Act, the Secretary and the National Invasive Species Council shall-

(1) give consideration to the 2002 report for the Louisiana Department of Wildlife and Fisheries titled "Nutria in Louisiana", and the 2002 document entitled "Eradication Strategies for Nutria in the Chesapeake and Delaware Bay Watersheds"; and

(2) develop, in cooperation with the State of Louisiana Department of Wildlife and Fisheries and the State of Maryland Department of Natural Resources, a long-term nutria control or eradication program, as appropriate, with the objective to significantly reduce and restore the damage nutria cause to coastal wetlands in the States of Louisiana and Maryland.

Approved April 23, 2003.

LEGISLATIVE HISTORY-H.R. 273:

CONGRESSIONAL RECORD, Vol. 149 (2003):

Apr. 8, considered and passed House.

Apr. 9, considered and passed Senate. 


\section{Appendix II: Washington GAP Analysis Project Predicted Distribution Map}
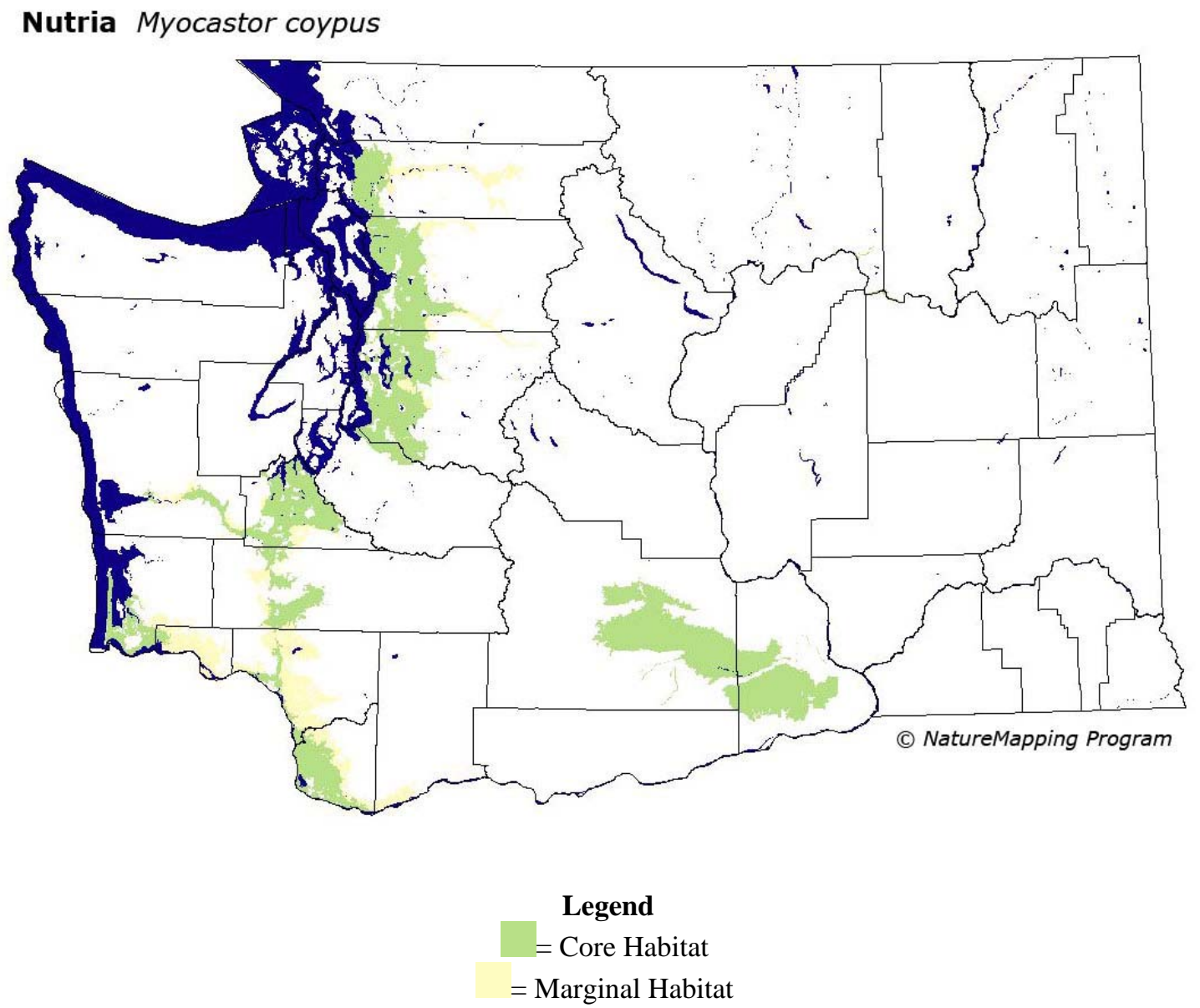

\section{Breeding Range Map}

The green area shows predicted habitats for breeding only. Habitats were identified using 1991 satellite imagery, other datasets and experts throughout the state, as part of the Washington Gap Analysis Project.

\section{Metadata}

Low elevation zones within [nutria] range, such as Sitka Spruce, Puget Sound Douglas-fir, Willamette Valley, the Cowlitz River, Woodland/Prairies Mosaic, and the steppe zones were core. Good habitat in these zones were irrigated farmlands, and fresh/water wetlands.

\section{Background}

Gap Analysis is a process of identifying areas of high conservation priority designed to be a proactive approach to conservation. Gap relies on information about current landcover and terrestrial vertebrates to identify habitat types and species that are poorly represented on reserves. The land cover map was made from 1991 satellite Thematic Mapper (TM) images. Areas of similar vegetation were delineated using the satellite images as a guide. The minimum mapping unit was 100 hectares. The distribution of breeding vertebrates was modeled using known range limits and habitat association. Programs written for Arc/Info select suitable habitat for each species, and then refine it by geographic and elevation limits based on knowledge of each species. The resulting maps were combined to provide maps showing centers of diversity, which can be overlaid with land ownership maps to determine areas of need for preserving all species. 


\section{Appendix III: Workshop Participants}

The following agencies and organizations were represented at the first session on April $24^{\text {th }}$ :

Portland State University

Center for Lakes and Reservoirs

Environmental Sciences and Resources Department

Oregon State University

Department of Fisheries and Wildlife

Department of Crop and Soil Science

Sea Grant

United States Fish and Wildlife Service

Pacific Region

Tualatin River National Wildlife Refuge

Ridgefield National Wildlife Refuge

USGS National Wetlands Research Center

United States Department of Agriculture

Animal Plant Health and Inspection Services

Wildlife Services

National Wildlife Research Center

Oregon

Washington

Maryland

Washington County

Clackamas County

National Resources Conservation Service

Forest Service

Environmental Protection Agency

United States Army Corps of Engineers

Oregon Department of Fish and Wildlife

Invasive Species and Wildlife Integrity

Sauvie Island Wildlife Area

Washington Department of Fish and Wildlife

Aquatic Nuisance Species

Region 6

La Conner District Office

Cowlitz Wildlife Area

Washington Department of Ecology

Washington Department of Natural Resources
Louisiana Department of Wildlife and Fisheries

Metro Regional Parks and Greenspaces

Clean Water Services

Yakama Nation Wildlife Resource Management

SOLV

Marion Soil and Water Conservation District

Polk Soil and Water Conservation District

West Multnomah Soil and Water Conservation District Tualatin Soil and Water Conservation District

Tualatin Hills Parks and Recreation District

Willamalane Parks and Recreation District

Ash Creek Water Control District

Wahkiakum Diking District

Multnomah County Vector Control

Alsea Watershed Council

North Coast Watershed Association

Puget Sound Action Team

City of Eugene Public Works

City of Albany Public Works

City of Sherwood Public Works

City of North Plains Public Works

City of Forest Grove Public Works

City of Beaverton Public Works

City of Portland Bureau of Environmental Services

City of Gresham Dept. of Environmental Services

City of Vancouver Greenways

Tualatin Hills Nature Park

Jackson Bottoms Wetland Preserve

Greenwood Resources

Intel Corporation

Oregon Garden

Riverside Golf and Country Club

Genesis Laboratories

Korean Broadcasting System

Clatskanie Beaver Drainage Improvement Company

The following agencies and organizations were represented at the second session on April $25^{\text {th }}$ :

Portland State University

US Fish \& Wildlife Service

United States Geological Survey

Oregon Department of Fish \& Wildlife

Washington Department of Fish \& Wildlife

Tualatin Hills Parks \& Recreation District

Clean Water Services
USDA/APHIS/Wildlife Services

National Wildlife Research Center

Oregon

Washington

Maryland

City of Gresham Department of Environmental Services Genesis Laboratories 


\section{Appendix IV: Workshop Session \#1 Agenda}

TIME $\quad \underline{\text { SUBJECT }}$

8:30 am Welcome and Introduction

8:35 am The Federal Aquatic Nuisance Species Task Force: Addressing Nutria as a National Concern

8:45 am ODFW's Perspective on Invasive Species

8:55 am A Worldwide Review of Nutria Introductions, Research and Management: A USGS Perspective

9:35 am Nutria Control and Eradication Efforts in the US: Implications for a Nationwide Management Strategy

10:15 am Break

10:30 am Nutria Control Methods and Some Current Research

11:10 am Louisiana Coastwide Nutria Control Program

11:50 pm Lunch

12:50 pm Nutria - The Search For Weapons Of Marsh

Destruction in Skagit County

$1: 30 \mathrm{pm}$

$2: 10 \mathrm{pm}$

$2: 50 \mathrm{pm}$

3:05 pm
Program

Nutria: What We Don't Know May Surprise You

\section{Break}

SPEAKER

Mark Sytsma, PSU

Dan Diggs, USFWS

Jim Gores, ODFW

Jacoby Carter, USGS

Stephen Kendrot, USDA
Gary Witmer, USDA

Edmond Mouton, LDWF
Mike Davison, WDFW

Brian Vaughn, CWS

Debbie Frankel, PSU

Justin Stevenson, USDA

Panel - Nutria impacts on restoration efforts and communities in the PNW (audience participation is encouraged)

Panelists: Bruce Barbarasch, Tualatin Hills Parks and Recreation District Matt Cleland, USDA/APHIS/Wildlife Services/Washington Lauri Mullen, Eugene Public Works Parks \& Open Space Division Tim Esary, City of Vancouver Greenways
4:05 pm Closing comments
Mark Sytsma, PSU
4:15 pm Adjourn

All 40 minute presentations include 10 minute question and answer session following talk. 


\section{Appendix V: Workshop Session \#2 Action Items}

- RESEARCH

o Behavior

- Feeding preferences

- Communication

- Relationship between burrowing and slope

- Interaction with substrate

- Mechanism of competition with other wetland mammals (ex. muskrat)

o Movement/dispersal

- Home range dynamics in linear systems

- Urban vs. non-urban

- Human effects on connectivity

- Importance of climate on distribution

- Winter temperatures

- Northern/southern limits of distribution

o Habitat preference

- Importance of hydrologic regime

- Reed canary grass facilitation

- Refugia

- Minimal requirements

o Demography

- Minimum sustainable population

- Habitat specific

- Modeling distribution and populations

o Impacts

- Burrowing

- Water quality/sediment loading

- Structural integrity

o Dikes/roads/stream banks/agricultural fields

- Salmon and waterfowl habitat

- Riparian and wetland vegetation

- Impacts relative to other species (ex. muskrat)

o Trapping Improvements

- Multiple capture traps

- Lures and toxicants

- Detection of small populations

- MANAGEMENT

0 Best management practices

- Rapid response plans

- Prevention

- Anti-nutria design of water structures

- Enforce regulations on relocating animals

o Stakeholders/partners

- Communication/coordination/leadership

- Funding sources 
o Scale of plan

- Regional (OR/WA/CA/ID)

- State plans

- Watershed plans

- Local governments

- Special districts

o Legislature/regulatory issues

- Live trapping and relocation

- Synch OR and WA laws

o Relationship between nutria population density and human acceptance/support

- $\quad$ AGENCY/ORGANIZATION COMMITMENTS

O 2007

- Local

- Gresham

o Signage to prevent people from feeding nutria

o Trapping program

- Eugene

o Trapping program

- Albany

o Trapping program

- Clean Water Services

o Trapping program

o Signage to prevent people from feeding nutria?

- Alsea (Joe Roehleder)

o Explore relationship between nutria and salmon habitat

- USDA/APHIS/Wildlife Services

- Disease study in Tillamook County

- Disease testing of aggressive nutria (w/ CWS)

- Monitoring Vancouver for tularemia in nutria

- Trap testing

- Lure/attractant development

- Best management practices

- Skagit County monitoring (w/ WDFW)

o Continue through 2010

- Portland State University

- Summary of nutria workshop

- PNW distribution map

- Impact on riparian restoration plantings (w/ CWS)

- Debbie Frankel thesis on nutria and water quality (w/ CWS)

- USFWS

- Proposal for funding from ODFW (w/ USGS)

- Explore coordination with CA and ID

o 2008

- USGS

Long-term nutria response program 
Appendix VI: Example of a Distribution/Density Map Request for Information

\section{TUALATIN RIVER WATERSHED NUTRIA DISTRIBUTION/DENSITY MAP}

\section{Tualatin River Watershed}

6th field HUCs

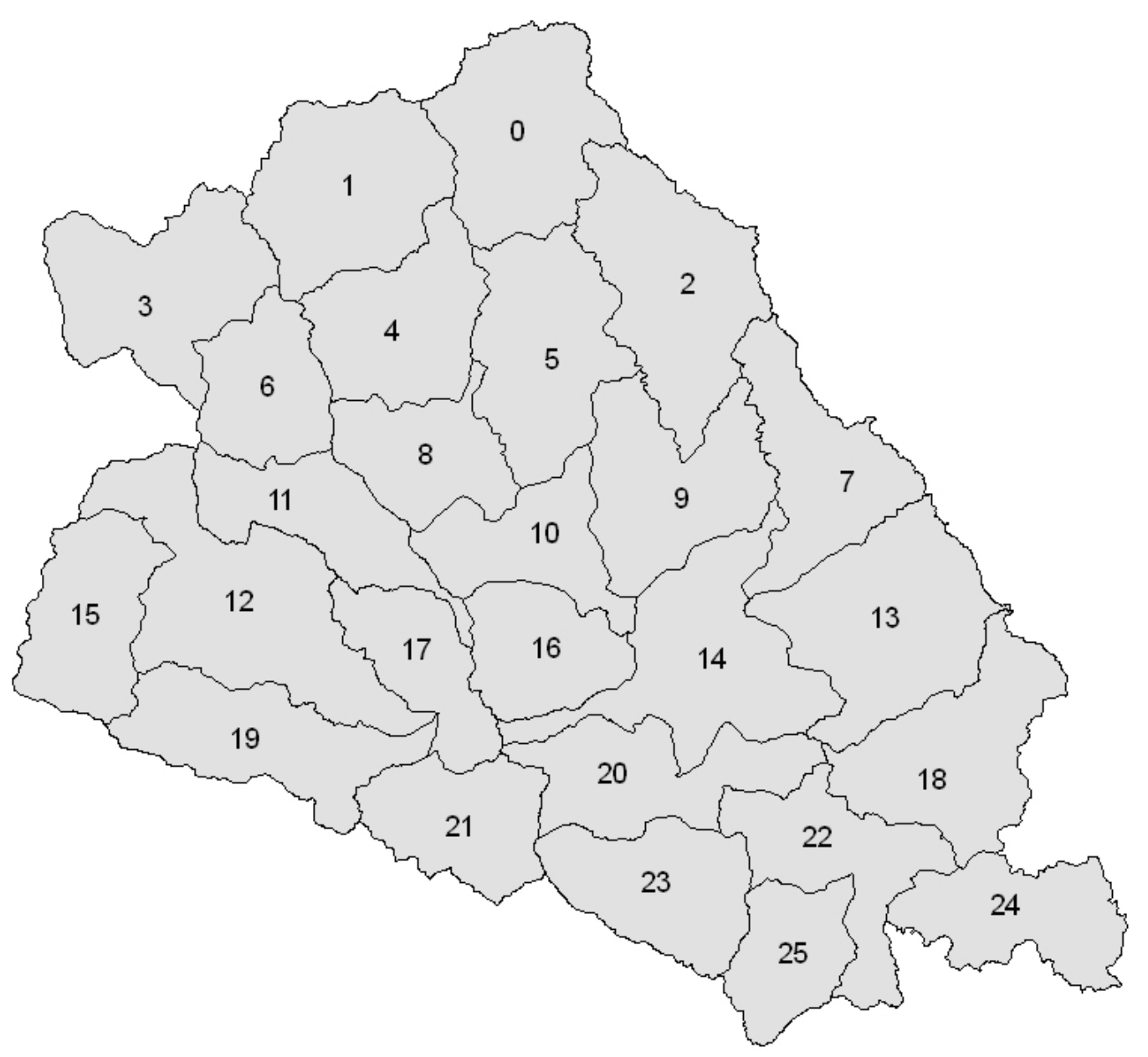


Using the map above, please estimate to the best of your ability the number of nutria currently present in each watershed using one of the following relative densities and mark in the table below:

0 individuals $\quad$ 1-10 individuals $\quad$ 11-100 individuals $\quad>100$ individuals

\begin{tabular}{|c|c|c|}
\hline & SUB-WATERSHED & NUTRIA \\
\hline 0 & Upper East Fork Dairy Creek & \\
\hline 1 & Upper West Fork Dairy Creek & \\
\hline 2 & Upper McKay Creek & \\
\hline 3 & Upper Gales Creek & \\
\hline 4 & Middle West Fork Dairy Creek & \\
\hline 5 & Lower East Fork of Dairy Creek & \\
\hline 6 & Middle Gales Creek & \\
\hline 7 & Upper Rock Creek-Tualatin River & \\
\hline 8 & Lower West Fork Dairy Creek & \\
\hline 9 & Lower McKay Creek & \\
\hline 10 & Lower Dairy Creek & \\
\hline 11 & Lower Gales Creek & \\
\hline 12 & Scoggins Creek-Sain Creek & \\
\hline 13 & Beaverton Creek & \\
\hline 14 & Lower Rock Creek-Tualatin River & \\
\hline 15 & Upper Tualatin River & \\
\hline 16 & Tualatin River & \\
\hline & Lower Tualatin River & \\
\hline & Fanno Creek & \\
\hline 19 & Middle Tualatin River & \\
\hline 20 & Christensen Creek-Tualatin River & \\
\hline & Wapato Creek & \\
\hline 22 & Rock Creek-Lower Tualatin River & \\
\hline & McFee Creek & \\
\hline & Saum Creek-Lower Tualatin River & \\
\hline & Chicken Creek & \\
\hline
\end{tabular}




\section{Appendix VII: Example of a Preliminary Nutria Habitat Suitability Model}

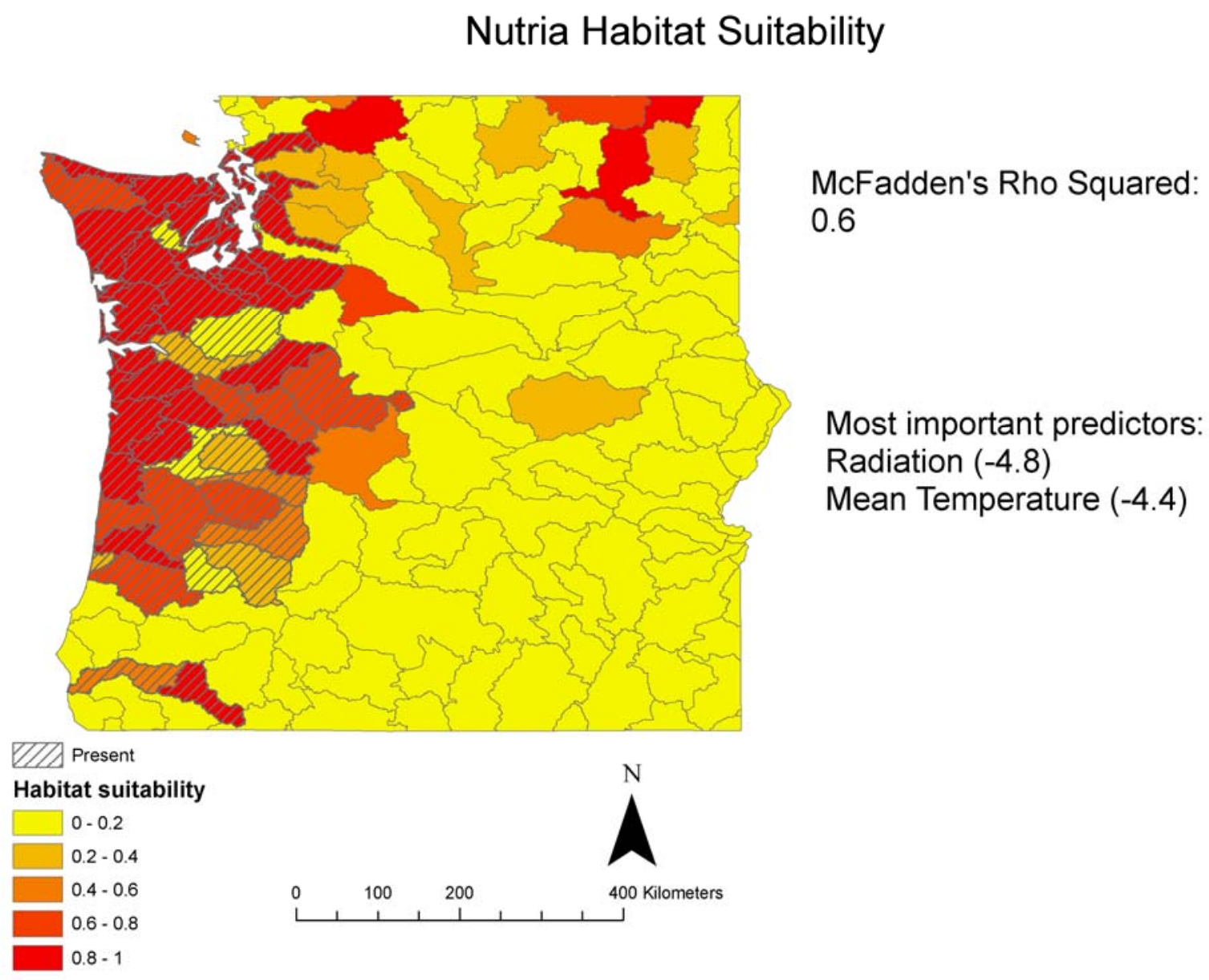

Developed by Dr. Thomas Stohlgren research team, NIISS 
Appendix VIII: GPS Study Plot Locations (Decimal Degrees)

Beaverton Creek West

W

Control $1-122.8371$

Control $2-122.8370$

Control $3 \quad-122.8367$

Control $4 \quad-122.8363$

Control $5 \quad-122.8361$

Study $1 \quad-122.8372$

Study $2 \quad-122.8359$

Study $3 \quad-122.8366$

Study $4 \quad-122.8364$

Study $5 \quad-122.8367$
$\mathrm{N}$

45.4929

45.4927

45.4926

45.4922

45.4921

45.4932

45.4921

45.4924

45.4923

45.4926
Beaverton Creek East

W

$\begin{array}{lll}\text { Control } 1 & -122.8321 & 45.4932\end{array}$

Control $2 \quad-122.8332 \quad 45.4930$

$\begin{array}{lll}\text { Control } 3 & -122.8323 & 45.4933\end{array}$

Control $4 \quad-122.8311 \quad 45.4933$

$\begin{array}{lll}\text { Control } 5 & -122.8325 & 45.4930\end{array}$

Study $1 \quad-122.8331 \quad 45.4930$

Study $2 \quad-122.8326 \quad 45.4930$

Study $3 \quad-122.8319 \quad 45.4932$

Study $4 \quad-122.8329 \quad 45.4929$

Study $5 \quad-122.8318 \quad 45.4933$

\begin{tabular}{lccccc} 
& \multicolumn{2}{c}{ Quatama } & & \multicolumn{2}{c}{ Englewood } \\
Control 1 & -122.9034 & 45.5205 & Control 1 & -122.7876 & 45.4436 \\
Control 2 & -122.9028 & 45.5200 & Control 2 & -122.7874 & 45.4439 \\
Control 3 & -122.9036 & 45.5213 & Control 3 & -122.7874 & 45.4432 \\
Control 4 & -122.9038 & 45.5208 & Control 4 & -122.7873 & 45.4431 \\
Control 5 & -122.9027 & 45.5201 & Control 5 & -122.7875 & 45.4437 \\
& & & & & \\
Study 1 & -122.9038 & 45.5208 & Study 1 & -122.7874 & 45.4438 \\
Study 2 & -122.9035 & 45.5212 & Study 2 & -122.7875 & 45.4440 \\
Study 3 & -122.9038 & 45.5212 & Study 3 & -122.7873 & 45.4432 \\
Study 4 & -122.9025 & 45.5202 & Study 4 & -122.7873 & 45.4432 \\
Study 5 & -122.9038 & 45.5211 & Study 5 & -122.7874 & 45.4434
\end{tabular}


Report on Nutria Management and Research in the Pacific Northwest-2007

Appendix IX: Example of a Research Plot Inventory

QU AT AM A - August 31

STUDY

CONTROL

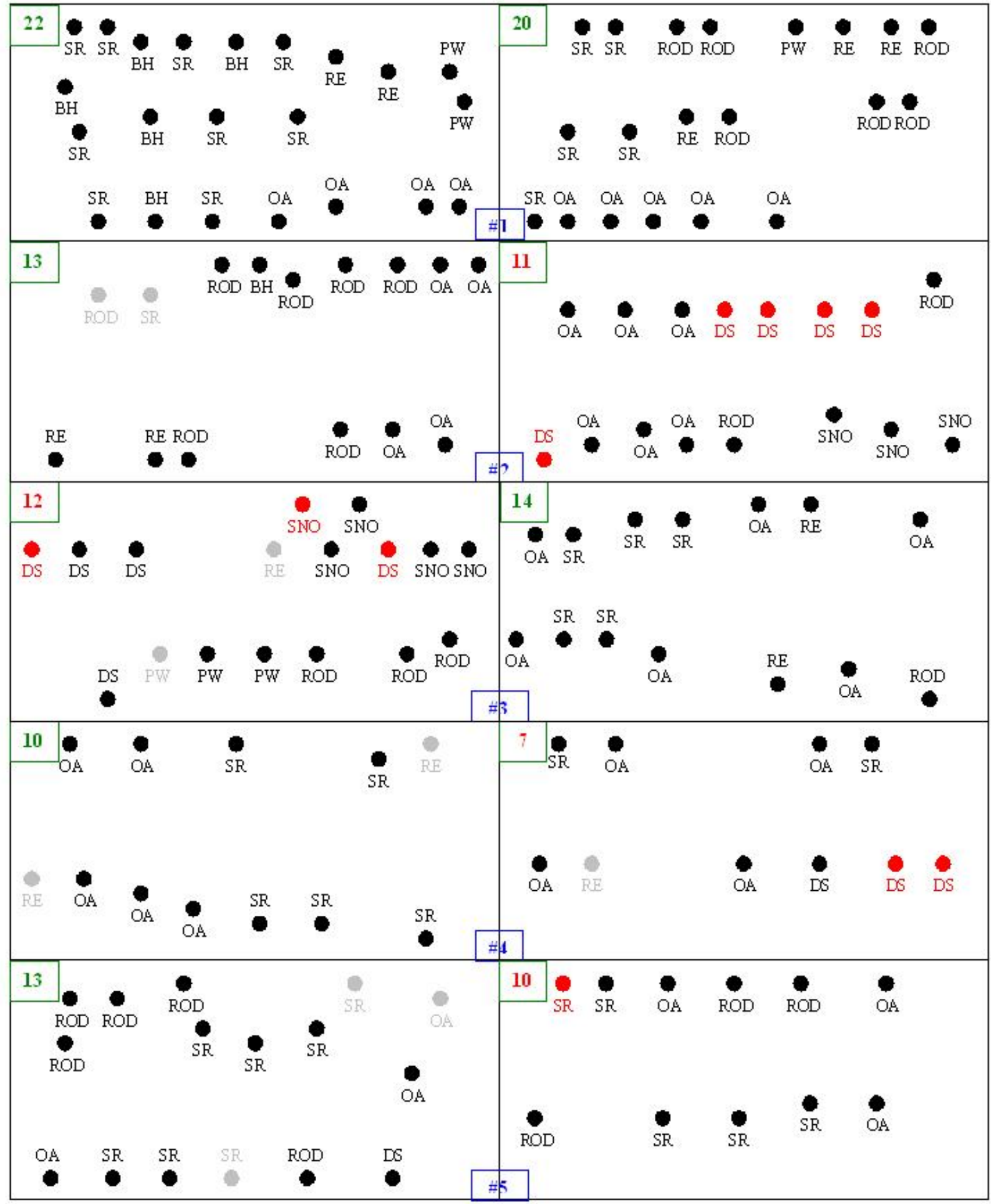




\section{Appendix X: Field Research Summary Data}

BEAVERTON CREEK WEST

Date

June 30, 2007

July 19, 2007

August 7, 2007

August 31, 2007

September 13, 2007

September 27, 2007

October 11, 2007

October 26, 2007

Date

June 30, 2007

July 19, 2007

August 7, 2007

August 31, 2007

September 13, 2007

September 27, 2007

October 11, 2007

October 26, 2007

Date

June 30, 2007

July 19, 2007

August 7, 2007

August 31, 2007

September 13, 2007

September 27, 2007

October 11, 2007

October 26, 2007

Date

June 30, 2007

July 19, 2007

August 7, 2007

August 31, 2007

September 13, 2007

September 27, 2007

October 11, 2007

October 26, 2007

\# Plants Damaged
N/A
0
0
1
1
0
0
0

Species Damaged

N/A

N/A

N/A

Pacific ninebark

Oregon ash

N/A

$\mathrm{N} / \mathrm{A}$

N/A

Cause of Damage

N/A

N/A

N/A

Desiccation

Nutria

N/A

$\mathrm{N} / \mathrm{A}$

N/A

\section{BEAVERTON CREEK EAST}

\# Plants Damaged
N/A
0
0
2
0
0
0
0

QUATAMA

\# Plants Damaged
N/A
6

Species Damaged
N/A
N/A
N/A
Douglas spirea
N/A
N/A
N/A
N/A

$\mathrm{N} / \mathrm{A}$
Cause of Damage

N/A

N/A

N/A

Desiccation

N/A

N/A

N/A

N/A $\underline{\text { Species Damaged }}$

N/A

Oregon ash, swamp rose, red elderberry, Pacific willow

Red osier dogwood, swamp rose, red elderberry

Douglas spirea, swamp rose N/A

Black hawthorne, swamp rose

Red osier dogwood

N/A
Cause of Damage

N/A

Mowing

Herbicide

Desiccation

N/A

Nutria, dessication

Nutria

N/A

\section{ENGLEWOOD PARK}

\# Plants Damaged
N/A
0
0
6

\section{0}

0

0

\section{Species Damaged}

N/A

N/A

N/A

Douglas spirea, red elderberry, Pacific willow

N/A

N/A

N/A

N/A
Cause of Damage

N/A

N/A

N/A

Desiccation, mowing

N/A

N/A

N/A

N/A 


\section{Appendix XI: Nutria Damage Questionnaire for USFWS Pacific Northwest Refuges}
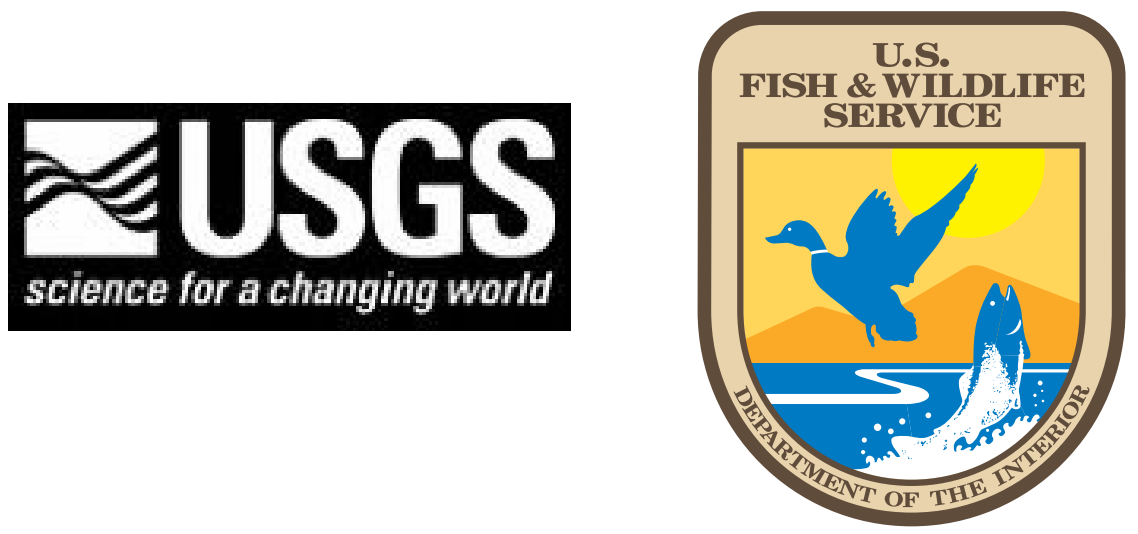

\section{Portland State

QUESTIONNAIRE

\section{Regional Impact of Nutria (Myocastor coypus) on Habitat Restoration Projects}

Trevor Sheffels

Center for Lakes and Reservoirs

Portland State University

\section{Please complete the following questions to the best of your ability.}

\section{$\underline{\text { Refuges }}$}

1. Please identify the refuge(s) you currently manage.

Include the name(s), location(s), your responsibilities, and how long you have managed the refuge(s).

For each question below, please specify the corresponding refuge from your list above.

\section{$\underline{\text { Nutria Presence/Absence }}$}

2. Have you or any of your employees ever seen nutria at your refuge(s)?

If not, then you do not need to answer the following questions. However, please return the questionnaire in order to provide information for a regional nutria distribution map.

3. In your opinion, do reproducing nutria populations currently exist at your refuge(s)? If yes, describe any refuge-wide nutria management strategies you are currently implementing (please include an annual cost estimate if possible). Also, please estimate the number of nutria being removed from your site(s) on an annual basis. 


\section{Nutria Impacts on Restoration Efforts}

4. Have you completed any habitat restoration projects on your refuge(s) in the last five years? If not, then you do not need to answer the following questions. However, please return the questionnaire in order to provide information for a regional nutria distribution map.

5. If yes, have you documented or noticed direct or indirect nutria damage being sustained by these projects? Please describe the nature of any damage.

6. Please list any plant/shrub/tree species that nutria seem to be specifically targeting at your habitat restoration site(s).

Please rank species from most targeted to least targeted.

\section{$\underline{\text { Economic Loss }}$}

7. What percentage of the restoration plantings would you estimate is being lost on an annual basis as a result of nutria damage?
less than $25 \%$
$25 \%-50 \%$
$51 \%-75 \%$
more than $75 \%$

8. What monetary amount would you estimate is being lost on an annual basis as a result of nutria damage to restoration planting efforts?

Please include the cost of plants/labor/trapping equipment/trapping hours/other management efforts/etc.

less than $\$ 1,000 \quad \$ 1,000-\$ 9,999 \quad \$ 10,000-\$ 100,000 \quad$ more than $\$ 100,000$

\section{$\underline{\text { Control/Mitigation }}$}

9. Please describe any efforts to mitigate nutria damage to your habitat restoration projects. Please include an estimate of the annual cost of these mitigation efforts if possible. 


\section{Appendix XII: USFWS Questionnaire Cover Letter}

\section{क Portland State}

$\underline{\text { Regional Impact of Nutria (Myocastor coypus) on Habitat Restoration Projects }}$

Dear USFWS Refuge Manager:

My name is Trevor Sheffels and I am a graduate at the Center for Lakes and Reservoirs at Portland State University. I am beginning a study on the regional impact of nutria on habitat restoration projects, and would like to invite you to participate. This study is being supported by United States Fish and Wildlife Service and United States Geological Survey.

You are being asked to take part because you are a refuge/restoration site manager who may potentially be experiencing nutria problems currently or at some point in the future. As part of the study, I am interested in your knowledge and information about nutria impacts, or lack thereof, on your site(s). I hope that the information I collect will help us to better understand nutria impacts to refuge/habitat restoration sites on a regional level. Responses will also be used to aid in the development of a regional nutria distribution map. If you decide to participate, you will be asked to complete the attached questionnaire, which involves answering questions about nutria damage on your site(s). It should take approximately five to ten minutes to complete. Completion of the questionnaire indicates your consent to participate in this research.

There is very minimal risk associated with your participation in the study. You may not receive any direct benefit from taking part in this study, but the study may help to increase knowledge about nutria impacts on refuge/restoration sites that may help others in the future.

Any information that is obtained in connection with this study and that can be linked to you or identify you will be kept confidential. Subject identities will be kept confidential by storing all information in a Microsoft Access database stored on a secure Portland State University server. All questionnaire responses will be presented in aggregate form in order to protect the identity of all questionnaire participants.

Participation is entirely voluntary. Your decision to participate or not will not affect your relationship with the researcher or with the Center for Lakes and Reservoirs at Portland State University in any way. If you decide to take part in the study, you may choose to withdraw at any time without penalty. Please keep a copy of this letter for your records.

If you have concerns or problems about your participation in this study or your rights as a research subject, please contact the Human Subjects Research Review Committee, Office of Research and Sponsored Projects, 600 Unitus Building, Portland State University, (503) 7254288 / 1-877-480-4400. If you have questions about the study itself, contact Trevor Sheffels at Portland State University, PO Box 751-ESR, 97207-0751; phone:(503) 725-9076; email:sheffels@pdx.edu.

Sincerely,

Trevor Sheffels

Center for Lakes and Reservoirs

Portland State University 